\title{
ROLE PODSTATNÝCH NÁLEŽITOSTÍ DEMOKRATICKÉHO PRÁVNÍHO STÁTU V ÚSTAVNÍ PRAXI ČESKÉ REPUBLIKY
}

\begin{abstract}
Streszczenie. Rola zasadniczych wymagań demokratycznego państwa prawnego $w$ praktyce konstytucyjnej Republiki Czeskiej. Kiedy definiujemy treść istotnych elementów demokratycznego państwa prawa, należy wziąć pod uwagę w szczególności fakt, że ta koncepcja odgrywa pięć możliwych ról w systemie konstytucyjnym Republiki Czeskiej: klauzula wieczności, ramy odniesienia w przeglądzie konstytucyjnym, materialny rdzeń konstytucji, tożsamość konstytucyjna Republiki Czeskiej oraz zestaw podstawowych wartości czeskiej konstytucji. Niezbędne elementy demokratycznego państwa prawa, w związku z ideami założycielskimi Konstytucji Republiki Czeskiej, zawierają element uniwersalny i szczególny. Trudno sobie wyobrazić tożsamość konstytucyjną, która tylko powiela konstytucyjne tożsamości innych państw, z drugiej strony nawet w czeskiej tożsamości konstytucyjnej z pewnością jest miejsce dla czeskich twórców konstytucyjnych, by zaakceptować uniwersalne zasady uznane w rodzinie zachodnich demokracji. To dalej określa szczególne zasady rozumiane jako podstawowe elementy demokratycznego państwa prawa w rozumieniu art. 9 ust. 2 czeskiej konstytucji.
\end{abstract}

Słowa kluczowe: demokratyczne państwo prawne; Konstytucja Republiki Czeskiej; klauzula wieczności; zasady konstytucyjne; zmiany konstytucji; nieodmienność konstytucji.

\section{1. ÚVOD}

Čl. 9 odst. 2 Ústavy ČR stanoví: „Změna podstatných náležitostí demokratického právního státu je nepř́ipustná“"1. Z dikce prvního odstavce čl. 9 Ústavy ČR, který předpokládá, že Ústava může být doplňována nebo měněna ústavními zákony, a ze systematiky čl. 9 Ústavy ČR lze vyvodit, že hlavním smyslem ustanovení čl. 9 odst. 2 Ústavy ČR je stanovit limity pro změny Ústavy. Přestože čl. 9 odst. 1 Ústavy ČR výslovně hovoří o změnách Ústavy, přikláním se k názoru Rychetského $(2015,94)$ a Šimíčka $(2010,151)$, že ochrana zakotvená v čl. 9 Ústavy ČR se vztahuje na celý ústavní pořádek. Vzhledem k tomu, že změny Ústavy jsou v ČR

* Univerzity Palackého v Olomouci, Právnická fakulta, Katedra ústavního práva, maxim. tomoszek@upol.cz.

${ }^{1}$ Pro úplnost je nutno uvést, že vládní návrh Ústavy ČR toto ustanovení původně neobsahoval. Zařazen byl až na základě doporučení ze Společné zprávy výborů České národní rady ze dne 12. 12. 1992 , tedy jen čtyři dny před přijetím Ústavy ČR - viz Holländer $(2005,324)$. Molek $(2014,83)$ to trefně označuje jako „věčnost na poslední chvíli““. 
ve srovnání s jinými státy poměrně běžné (zatím byla za 25 let př́mo novelizována celkem osmkrát), stejně jako přijímání dalších součástí ústavního pořádku a jejich změny (celkem bylo od účinnosti Ústavy ČR přijato 18 ústavních zákonů) ${ }^{2}$, má vymezení limitů pro změny ústavního pořádku významný praktický dopad.

Hlavní otázky související s výkladem čl. 9 odst. 2 Ústavy ČR jsou:

- vymezení předmětu ochrany, tedy definování, co je obsahem pojmu podstatné náležitosti demokratického právního státu;

- praktické důsledky uplatnění klauzule věčnosti, tedy zejména kdo je povolán $\mathrm{k}$ ochraně podstatných náležitostí demokratického právního státu a jakými nástroji nebo prostředky může reálně zabránit přijetí ústavního zákona, který by čl. 9 odst. 2 Ústavy ČR porušoval (Šimíček 2010, 158);

- cíl ochrany podstatných náležitostí demokratického právního státu, resp. role ustanovení čl. 9 odst. 2 Ústavy ČR v ústavním systému ČR, což je i ústředním předmětem zájmu tohoto textu.

Odpověd' na otázky uvedené ve druhé odrážce poskytl Ústavní soud v nálezu v tzv. kauze Melčák, kde dovodil, že z čl. 9 odst. 2 Ústavy ČR ve spojení s čl. 83 Ústavy ČR vyplývá pravomoc Ústavního soudu zrušit ústavní zákon, který by měnil podstatné náležitosti demokratického právního státu. Přestože by patrně bylo vhodnější, kdyby v praxi ustanovení čl. 9 odst. 2 Ústavy ČR vedlo k sebeomezení Parlamentu, jak podotýká Filip, nelze si v tomto směru dělat velké iluze, nebot' již bylo předsedajícím Poslanecké sněmovny připuštěno hlasování o návrhu zjevně protiústavního zákona (konkrétně o zavedení trestu smrti) (Filip 2003, 112). Ústavní soud však svým citovaným rozhodnutím některé další otázky vytvořil, což bude podrobněji rozebráno dále $\mathrm{v}$ textu.

Při snaze odpovědět na první otázku, tedy vymezit obsah tohoto pojmu, je v podstatě potřeba odpovědět na otázku „,co musí být splněno, abychom o České republice mohli říci, že se jedná o demokratický právní stát?“, př́ípadně lze tuto otázku postavit i opačně: ,za předpokladu, že v současnosti Ústava ČR zakotvuje demokratický právní stát, změna kterých prvků ústavního systému by znamenala, že by ČR přestala být demokratickým právním státem?“

V odborné literatuře a $\mathrm{v}$ judikatuře Ústavního soudu je pojem demokratického právního státu poměrně obsáhle a široce definován (Tomoszek 2015b, 56). Je postaven na několika klíčových širokých principech (ve formální oblasti je to zejména právní jistota, $v$ oblasti organizačně-procesní např́ílad dělba moci, v materiální oblasti pak především ochrana základních práv), které jsou dále konkretizovány ve velkém množství derivovaných dílčích principů. Podle Ústavního soudu zahrnuje demokratický právní stát také určité hodnotové prvky, jako např. svobodu, rovnost, důstojnost nebo spravedlnost. Vzhledem ke komplexitě pojmu demokratický právní stát jsou v něm obsaženy i protichůdné principy, které se

${ }^{2}$ Od roku 2013 se stav nezměnil, takže jsou stále platné závěry učiněné v Tomoszek (2013, 239 an.) 
mohou ocitnout $\mathrm{v}$ určitém napětí a je nutné je vyvažovat, což s sebou zpravidla nese i určité jejich omezení. Za podstatné náležitosti demokratického právního státu je tedy možné považovat jen jádro principů, které chápeme jako součásti demokratického právního státu. Při vymezení obsahu pojmu podstatné náležitosti demokratického právního státu je však také důležité zohlednit, že limitace změn ústavního pořádku není jediným účelem, který zakotvení podstatných náležitostí demokratického právního státu v Ústavě ČR sleduje.

Podstatné náležitosti demokratického právního státu tvoří ty částí principů obsažených v pojmu demokratický právní stát, které nelze změnit. A to ne proto, že by to nebylo myslitelné nebo fakticky možné, protože pak by bylo ustanovení čl. 9 odst. 2 Ústavy zbytečné, ale právě proto, že fakticky takové změny proveditelné jsou, ovšem $\mathrm{s}$ vědomím rizik, která s sebou přinášejí, jsme se vědomě rozhodli jejich změnu vyloučit (Luhmann 1983, 143 an.).

Tím však není vyloučena jejich faktická změna - pokud se subjekt disponující potřebnou faktickou mocí rozhodne, že v ČR zavede totalitu, Ústava mu v tom nezabrání (Preuss 2015, 244). To by mohl jedině lid při realizaci práva na odpor (Šimíček 2009, 222).

Spíše tak lze čl. 9 odst. 2 Ústavy považovat za omezení principu vlády většiny, plynoucího ve vztahu k Ústavě z čl. 9 odst. 1 Ústavy (Ústavu lze měnit a doplňovat ústavními zákony), kdy určité změny nejsou prrípustné ani při dosažení kvalifikované většiny. Principy demokratického právního státu jsou z valné většiny určeny právě $\mathrm{k}$ ochraně menšin (rovnost před zákonem, vázanost státu právem, garance základních práv apod.). Parlament však v důsledku způsobu, jakým je ustavován, není $\mathrm{k}$ ochraně menšin př́liš dobře způsobilý - naopak preferuje řešení, která vyhovují většině. K ochraně uvedených základních principů sloužících k ochraně menšin tedy musí být povolán orgán, který nemá motivaci plynoucí z krátkodobého politického efektu. Tomuto pojetí je v ústavním systému ČR nejblíže Ústavní soud. Nejedná se totiž o orgán založený na politické legitimitě, nýbrž na legitimitě odborné 3 .

Pokud chceme vymezit možné role, které může pojem podstatné náležitosti demokratického právního státu hrát $\mathrm{v}$ ústavním systému ČR, je nutné začít od jeho účelu, kterým je působit jako limit pro změny Ústavy ČR, tedy jako klauzule věčnosti (Preuss 2015, 36 an.). Ze skutečnosti, že Ústavní soud provádí přezkum ústavních zákonů z pohledu jejich slučitelnosti s čl. 9 odst. 2 Ústavy ČR, je nutno vyvodit, že podstatné náležitosti demokratického právního státu vystupují také $\mathrm{v}$ roli referenčního rámce přezkumu.

Někteří autoři $\mathrm{v}$ souvislosti s pojmem podstatných náležitostí demokratického právního státu zmiňují také pojem materiální jádro (nebo ohnisko) ústavy,

${ }^{3}$ Ovšem i zde je možné najít určité problémy, jako např. možnost opětovného jmenování, kde se již v praxi projevilo, že způsob, jakým soudce v minulosti rozhodoval, byl pro prezidenta nebo Senát v procesu jmenování rozhodující. 
zejména v té souvislosti, zda se jedná o synonyma či různé pojmy (Preuss 2015, 36 an.; Molek 2014, 7; Holländer 2005, 325; Šimíček 2009, 218 an.). Rovněž se lze v této souvislosti setkat s pojmem ústavní identity (Sobek 2011, 218 an.), což zároveň vyvolává úvahy, zda je možné podstatné náležitosti demokratického právního státu považovat za hodnotový rámec či hodnotové ukotvení Ústavy ČR (Sobek 2011, 411; Tomoszek 2010a, 325 an.).

Cíle ochrany podstatných náležitostí demokratického právního státu v Ústavě ČR pak lze spatřrovat zejména v:

- plnění stabilizační funkce, tedy z konzervování určitých klíčových ústavních řešení, který definují povahu České republiky jako demokratického právního státu;

- reakci na historické zkušenosti, kdy nevhodné či zlovolné zásahy do ústavního systému měly fatální důsledky;

- ochraně před neuváženými nebo nevhodnými změnami Ústavy ČR nebo jiných součástí ústavního pořádku;

- ochraně liberální demokracie, což je významné zejména ve světle zkušeností jiných středoevropských států, které čelí fenoménu tzv. ústupu demokracie (democratic backsliding);

- ochraně před zneužitím moci aktuální politickou nebo společenskou většinou.

Podrobnější rozbor uvedených rolí, které mohou podstatné náležitosti demokratického právního státu hrát $\mathrm{v}$ ústavním systému ČR, a tedy vazby tohoto pojmu na další ústavní pojmy a zároveň hlubší pochopení jeho účelu, je důležitým předpokladem pro interpretaci jeho obsahu. Této problematice budou věnovány následující části textu.

\section{KLAUZULE VĚČNOSTI}

$\mathrm{Z}$ pohledu terminologického je pojem klauzule věčnosti doslovným překladem německého pojmu Ewigkeitsklausel, kterým se označuje čl. 79 odst. 3 GG. Smyslem tohoto ustanovení je chránit Základní zákon před změnou týkající se základních principů spolkového uspořádání, základních principů ochrany lidských práv, právního státu, suverenity lidu a práva na občanskou neposlušnost, a to zejména $\mathrm{v}$ důsledku negativních historických zkušeností (Kommers, Miller, Ginsburg 2012, 285). Tyto úvahy vedou k formulaci doktríny tzv. obranyschopné, nebo bojovné, bránící se demokracie (Streitbare Demokratie). Pokud určité zásahy do ústavního systému považujeme za nepřípustné, může se jevit jako legitimní vyloučit ze soutěže politické strany, které by je chtěly realizovat, protože přece nechceme, aby demokratická společnost jen mlčky přihlížela své zkáze (Murphy 2007, 521, 524).

\footnotetext{
${ }^{4}$ Ve vztahu k Základnímu zákonu SRN viz Dreier (1994, 742).
} 
Proto může Spolkový ústavní soud rozhodnout o ztrátě občanských práv, pokud jsou zneuživána $\mathrm{k}$ boji proti demokratickému režimu a právům ostatních, a také o rozpouštění politických stran, a konečně právo na odpor (Morawska 2003, 67). Negativní historické zkušenosti byly zdrojem zakotvení obdobného ustanovení i do Ústavy ČR ${ }^{5}$, ovšem koncepce vymezení limitů pro změny ústavy byla zvolena odlišně, formou neurčitého pojmu, který musí být podrobněji konkretizován, zejména judikaturou ÚS.

Institut klauzule věčnosti představuje snahu o vyřešení několika ústředních sporů ústavnosti, resp. práva vůbec, a to zejména na základě negativních historických zkušeností. Jedná se o střet principu demokratického rozhodování většiny (v souvislosti s principem suverenity lidu) s principem ochrany menšin (tedy že většinovým rozhodnutím nelze zakotvit cokoli) (podobně Preuss 2015, 52), ale $\mathrm{v}$ určitém smyslu také o střet suverenity lidu a principu reprezentativní demokracie (tedy že ani kvalifikovaná většina v Parlamentu nemůže ústavním zákonem přijmout pravidla, která by byla $\mathrm{v}$ rozporu s vůlí lidu) (Fassbender 2003, 119; Sobek 2011, 411), a v nejobecnějším pohledu o střet právní jistoty či pořádku a spravedlnosti (Stein, Shand 1974, 10 právo nemůže být extrémně nespravedlivé (Radbruch 1946, 105). V tomto obecném pohledu jde tedy o střet koncepcí pozitivního práva a přirozeného práva (Sobek 2011, 402 an.). Pokud jdeme více do hloubky, dostává se tento střet do rozměru legitimity, tedy vztahu mezi mocí ustavující a ustavenou (Sobek 2011, 411-412; Preuss 2015, 65 an.).

$\mathrm{V}$ reakci na zkušenosti z druhé světové války vyložil koncept klauzule věčnosti hned ve svém prvním rozhodnutí Spolkový ústavní soud SRN, když připustil možnost, že i ustanovení Základního zákona může být nicotné. Podle Spolkového ústavního soudu totiž existují ústavní principy tak zásadního charakteru, že zavazují i ústavodárce, a ostatní ústavní ustanovení, která tento zásadní charakter nemají, mohou být nicotná, protože těmto fundamentálním principům odporují6. Tento př́stup vychází z konceptu obsaženého v tzv. Radbruchově formuli (Radbruch 1946, 105), který reflektuje např. R. Alexy ve své poměrně aktuální definici pojmu práva (Alexy 2009a, 161). Deklarace nějakých zásad jako nezměnitelných je podle Luhmanna nutná proto, že fakticky změnitelná tato pravidla jsou, at' již v důsledku změny společenských podmínek, revoluce, či jinak (Luhmann 1983, 143 an.).

Koncepce nezměnitelných ustanovení s sebou přináší řadu logických paradoxů. Jedním z nich je paradox tzv. neomezené demokracie, čili střet mezi principem „můžeme stanovit cokoli“" s principem „můžeme zrušit cokoli“ (Sobek 2011, 405). Objevuje se zde však také paradox legitimity (resp. suverenity). Z pohledu parlamentu je totiž nutné si uvědomit, že pokud by popřel nebo zrušil ústavu či její demokratické základy, poprel by tím vlastně i svou legitimitu, kterou z této ústavy

\footnotetext{
${ }^{5}$ Čl. 79 odst. 3 Základního zákona SRN.

${ }^{6}$ Nález Ústavního soudu ze dne 10. září 2009, sp. zn. Pl. ÚS 27/09, část IV.
} 
čerpá. Protože by svou legitimitu ztratil, byly by jeho činy také nelegitimní a tudíž neplatné. Totéž pravidlo platí i pro lid, byt' v poněkud modifikované podobě. Pokud by lid chtěl popř́t omezit svou suverenitu, limitovat své právo mít práva, zničil by svou schopnost dávat legitimitu politickému systému a tím i v těchto otázkách rozhodovat (Murphy 2007, 507).

Klauzule věčnosti tedy chrání určité prvky ústavního systému před změnou provedenou legitimně, tj. právními postupy. To však neznamená, že by nebylo možné je změnit fakticky, tedy mimoprávně, např. revolucí. Zde je nutné si uvědomit, že ústava může sebe sama chránit pouze v rovině práva. Pokud však dojde k využití bezprávních postupů, právně se proti nim bránit nelze. Na druhou stranu, i když není možné takovým bezprávním změnám právně zabránit, je důležité, že z pohledu práva nejsou legitimní, a tudíž v okamžiku znovunastolení právního režimu je možné tyto změny anulovat a jejich původce přivést $\mathrm{k}$ odpovědnosti. Úlohou klauzule věčnosti tedy není ochránit daný stát před revolucí vedoucí k totalitnímu režimu, nýbrž před neuváženými právními změnami, jimiž by se právní stát postupně, $v$ rámci fenoménu označovaného jako democratic backsliding (podrobněji viz Bermeo 2016, 5-19) přeměnil v totalitní režim. Zjednodušeně řečeno, pokud chceme hrát podle pravidel demokratického právního státu, klauzule věčnosti nám říká, jaké změny by byly porušením těchto pravidel.

\section{REFERENČNÍ HLEDISKO PŘEZKUMU}

Budeme-li realizovat ochranu podstatných náležitostí demokratického právního státu $\mathrm{v}$ rámci jejich funkce klauzule věčnosti prostřednictvím přezkumu ústavních zákonů před Ústavním soudem, samotný pojem podstatných náležitostí demokratického právního státu bude muset být uplatněn jako referenční hledisko tohoto přezkumu. Podle Ústavního soudu však mohou podstatné náležitosti demokratického právního státu hrát roli také v jiných situacích. Celkově si lze jejich použití jako referenčního rámce přezkumu představit ve třech kontextech:

a. primárně se jedná o přezkum souladu ústavních zákonů s čl. 9 odst. 2 Ústavy ČR, jak bylo demonstrováno v kauze Melčák ${ }^{7}$,

b. sekundárně jde o hodnocení evropského práva z pohledu principu Solange, tedy dodržení „,věrnosti“ evropskému právu, jak ÚS ČR argumentoval v řadě svých evropských nálezů (např. cukerné kvóty ${ }^{8}$ nebo léková vyhláška ${ }^{9}$ ) a fakticky provedl v kauze slovenské důchody XVII ${ }^{10}$,

\footnotetext{
${ }^{7}$ Př́ípad Jihozápad, I BVerfGE 14 (1951).

${ }^{8}$ Nález Ústavního soudu ze dne 10. září 2009, sp. zn. Pl. ÚS 27/09.

${ }^{9}$ Nález Ústavního soudu ze dne 8. března 2006, sp. zn. P1. ÚS 50/04.

${ }^{10}$ Nález Ústavního soudu ze dne 16. ledna 2007, sp. zn. Pl. ÚS 36/05.
} 
c. s tím souvisí preventivní přezkum souladu mezinárodních smluv podle čl. 10a s ústavním pořádkem podle čl. 87 odst. 2 Ústavy ČR ${ }^{11}$.

V př́ípadě přezkumu ústavních zákonů je použití podstatných náležitostí demokratického právního státu jako referenčního rámce přezkumu jasně dáno zněním čl. 9 odst. 2 Ústavy ČR. V tomto směru nelze než souhlasit s ÚS ČR, který již v nálezu Pl. ÚS 19/93 konstatoval:

České právo není založeno na svrchovanosti zákona. Nadřazenost zákonů nižším právním normám neznamená ještě jejich svrchovanost. Dokonce ani ve smyslu rozsahu zákonodárné kompetence v rámci ústavního státu nelze hovořit o svrchovanosti zákona. V pojetí ústavního státu, na kterém je založena Ústava České republiky, není právo a spravedlnost předmětem volné dispozice zákonodárce a tím ani zákona, protože zákonodárce je vázán určitými základními hodnotami, jež Ústava prohlašuje za nedotknutelné. Ústava České republiky např. v čl. 9 odst. 2 stanoví, že ,změna podstatných náležitostí demokratického právního státu je nepř́ipustná'. Tím jsou konstitutivní principy demokratické společnosti v rámci této Ústavy postaveny nad zákonodárnou kompetenci a tím ,ultra vires' Parlamentu. S těmito principy stojí a padá ústavní stát. Odstranění některého $\mathrm{z}$ těchto principů, provedené jakýmkoli, byt’ i většinovým anebo zcela jednomyslným rozhodnutím parlamentu, by nemohlo být interpretováno jinak, než jako odstranění tohoto ústavního státu jako takového ${ }^{12}$.

Na toto pojetí pak zcela logicky navázal v nálezu Pl. ÚS 27/09, kde nutnost přezkumu výslovně vztáhl i na ústavní zákony:

Artikuluje-li Ústavní soud nezbytnost vztažení kategorie ústavních zákonů do rámce pojmu „,zákon“ v čl. 87 odst. 1 písm. a) Ústavy z pohledu přezkumu jejich souladu s čl. 9 odst. 2 Ústavy, a to s př́padnými derogačními důsledky, činí tak v návaznosti na svoji judikaturu počínající klíčovým nálezem sp. zn. Pl. ÚS 19/93 a činí tak v souladu s hodnotami a principy, jimiž se řídí ústavní systémy v demokratických zemích. Ochrana materiálního jádra Ústavy, tj. imperativ nezměnitelnosti podstatných náležitostí demokratického právního státu dle čl. 9 odst. 2 Ústavy, není pouhým apelem, proklamací, nýbrž ústavním ustanovením s normativními důsledky. Alexander Hamilton v čl. 78 Listů Federalistů ukázal, že „,prostředníkem mezi lidem a zákonodárným sborem mají být soudy, aby mimo jiné udržovaly zákonodárství v mezích jeho pověření“ (poznámka pod čarou č. 11). Bez uvedeného promítnutí čl. 9 odst. 2 Ústavy do interpretace ustanovení čl. 87 odst. 1 písm. a) Ústavy by v něm zakotvená nepřípustnost změny podstatných náležitostí demokratického právního státu pozbyla normativní povahy a zůstala toliko politickou, př́íp. morální výzvou.

U tohoto využití je nutno přemýšlet o tom, zda je současný model vytvořený Ústavním soudem v kauze Melčák skutečně tím nejvhodnějším. Za prvé zde samozřejmě přetrvává problém legitimity - ÚS ČR musel sám velmi extenzivně vyložit Ústavu ČR, což bylo kritizováno (Kudrna 2009, 344) zejména z pohledu principu legality, konkrétně do něj řazené zásady enumerace veřejnoprávních pretenzí. Bylo by proto legitimnější a souladnější s principy demokratického právního státu, kdyby pravomoc ÚS ČR provádět přezkum ústavních zákonů byla do

${ }^{11}$ Nález Ústavního soudu ze dne 31. ledna 2012, sp. zn. Pl. ÚS 5/12.

${ }^{12}$ Srov. nález Ústavního soudu ze dne 26. listopadu 2008, sp. zn. Pl. ÚS 19/08 a nález Ústavního soudu ze dne 3. listopadu 2009, sp. zn. Pl. ÚS 29/09. 
Ústavy ČR výslovně zakotvena. Tím by se zároveň vyřešil druhý problém, který v souvislosti s touto pravomocí existuje, a to je absence jakékoliv procesní úpravy, včetně návrhového oprávnění. $V$ podstatě se tak dnes musí přiměřeně aplikovat úprava ostatních typů řízení před ÚS ČR, což ovšem působí procesní potíže, jak se velmi dobře ukázalo v kauze Melčák (Kudrna 2009, 344-345).

Konečně třetí problém aktuálního modelu spočívá $\mathrm{v}$ tom, že je prováděn jako následná kontrola ústavnosti, tedy až poté, co je ústavní zákon schválen. Tento postup je však podle mne problematický hned z několika důvodů, proto se domnívám, že v prrípadě kontroly souladu ústavních zákonů s podstatnými náležitostmi demokratického právního státu by bylo vhodnější ji provádět preventivně ${ }^{13}$. Mezi zmíněnými problémy je nutno na prvním místě zmínit, že musí být „protiústavní“ ústavní zákon nejprve schválen, aby mohl být přezkoumán. $\mathrm{Z}$ toho vyplývá na prvním místě riziko, zvláště $\mathrm{s}$ vědomím absence procesní úpravy a návrhových oprávnění, a také ve spojitosti s neurčitostí pojmu podstatných náležitostí demokratického právního státu, že k přezkumu vůbec nemusí dojít, protože nikdo nenavrhne jeho přezkum. $\mathrm{V}$ důsledku toho i „protiústavní ústavní zákon může být součástí ústavního pořádku, jako tomu bylo a je v případě ústavní zákona o rozpuštění Poslanecké sněmovny z roku 1998. Ten byl v odborné literatuře hodnocen značně kriticky ${ }^{14}$, ale přesto kvůli absenci návrhu na jeho přezkum, resp. zrušení, zůstal součástí ústavního pořádku.

Je samozřejmě možné namítat, že ani preventivní přezkum tento problém nevyřeší, protože ani v rámci preventivního přezkumu nemusí nutně dojít $\mathrm{k}$ podání návrhu a k zahájení řízení před ÚS. S touto výhradou nelze než souhlasit, ovšem i tento problém lze vyřešit - zavedením obligatorní preventivní kontroly ústavních zákonů Ústavním soudem z pohledu slučitelnosti s podstatnými náležitostmi demokratického právního státu. V některých státech je vyjádření Ústavního soudu $\mathrm{v}$ procesu změn ústavy obligatorní součástí ústavodárného procesu ${ }^{15}$, což má za výsledek nejen vyšší kvalitu přijímaných zákonů, ale také posiluje rigiditu ústavy. Vzhledem k množství ústavních zákonů přijímaných v ČR by vyšší rigidita Ústavy ČR byla cenným vedlejším účinkem navrhované právní úpravy (Tomoszek 2013, 239 an.).

V neposlední řadě je třeba zmínit problém nutnosti rušit ústavní zákon v př́ipadě, že je shledán rozpor s podstatnými náležitostmi demokratického právního státu, což zbytečně vyostřuje konflikt mezi mocí zákonodárnou a soudní. Preventivní kontrola by umožnila př́padný problém identifikovat ještě $\mathrm{v}$ průběhu ústavodárného procesu a bud' jej rovnou napravit volbou jiného řešení, souladného s podstatnými náležitostmi demokratického právního státu, nebo alespoň zbytečně nevkládat energii a politický potenciál do neuskutečnitelného projektu.

${ }^{13}$ Nález Ústavního soudu ze dne 21. prosince 1993, sp. zn. Pl. ÚS 19/93, část A.

${ }^{14}$ Nález Ústavního soudu ze dne 10. září 2009, sp. zn. Pl. ÚS 27/09, část IV.

${ }^{15}$ Např. Chilská Ústava z roku 1980 v čl. 82 odst. 2 nebo Rumunská Ústava z roku 1991 v čl. 146 (a). Podrobněji viz Gözler (2008, 4 an.). 
Pokud přejdeme k problematice evropského práva, a tedy zásady Solange, vychází Ústavní soud ČR z toho, že ochrana národní ústavní identity je nejen principem formulovaným ústavními soudy některých členských státü ${ }^{16}$, ale také principem evropského práva (podrobněji viz Zbíral 2014,112-133) (viz také dále část věnovanou ústavní identitě ČR). Volba podstatných náležitostí demokratického právního státu jako limitu pro evropské právo se jeví zcela logicky, nebot' pokud mají být určité otázky mimo dispozici ústavodárce (a tedy v důsledku i mimo dispozici suveréna), nemůže ústavodárce ani suverén přenést pravomoc měnit tyto otázky ani na Evropskou unii či jinou mezinárodní organizaci. Při tom je však nutné si uvědomit, že právní systém EU je vybudován na určitých základních principech, označovaných za obecné principy práva. Patř́ mezi ně např. princip právní jistoty, princip proporcionality, ochrana základních práv, princip rovnosti jako obecný princip (tedy neakcesorická rovnost) (Jacobs 2007, 50).

Konečně třetí situace, kdy podstatné náležitosti demokratického právního státu figurují v Ústavě ČR jako referenční hledisko přezkumu, je podle mne přezkum souladu mezinárodních smluv podle čl. 10a Ústavy ČR s ústavním pořádkem prováděný v řízení podle čl. 87 odst. 2 Ústavy ČR.

\section{MATERIÁLNÍ JÁDRO (OHNISKO) ÚSTAVY ČR}

V souvislosti s podstatnými náležitostmi demokratického právního státu se často používá také pojem materiální jádro či materiální ohnisko ústavy (Holländer 2005, 313; Šimíček 2009, 217 an.; Molek 2014 a další). Např. Holländer používá pojem materiální ohnisko ústavy jako synonymum pro podstatné náležitosti demokratického právního státu, nebo lépe řečeno označuje jako materiální ohnisko ústavy její nezměnitelné části, které Ústava ČR definuje pomocí pojmu podstatné náležitosti demokratického právního státu (Holländer 2005, 325). Tento pohled v zásadě vychází z judikatury Ústavního soudu, který však pojem materiální ohnisko v zásadě volně zaměňuje s pojmem materiální jádro, případně dokonce s pojmem nezměnitelná ustanovení (Preuss 2015, 42). V nálezu v kauze Melčák v části IV. nejprve uvádí:

Ústavní soud ve své dosavadní judikatuře důrazně dal najevo nezbytnost ochrany materiálního ohniska ústavního pořádku ${ }^{17}$,

${ }^{16}$ Jako první ji formuloval Spolkový ústavní soud SRN v rozhodnutích Solange I, 37 BVerfGE 271 (1974), a Solange II, 73 BVerfGE 339 (1986), podrobněji k vývoji judikatury viz Kommers, Miller, Ginsburg (2012, 325 an.); dále lze uvést př́íklad rozhodnutí polského Ústavního tribunálu ze dne 11. 5. 2005, sp. zn. K 18/04, rozhodnutí britského Nejvyššího soudu ze dne 22. ledna 2014, ve věci R (on the application of HS2 Action Alliance Limited) (Appellant) v The Secretary of State for Transport and another (Respondents), sp. zn. [2014] UKSC 3 a další.

${ }^{17}$ Nález Ústavního soudu ze dne 10. září 2009, sp. zn. Pl. ÚS 27/09, část IV. 
ovšem o několik odstavců dále dochází k závěru, že:

Ochrana materiálního jádra Ústavy, tj. imperativ nezměnitelnosti podstatných náležitostí demokratického právního státu dle čl. 9 odst. 2 Ústavy, není pouhým apelem, proklamací, nýbrž ústavním ustanovením s normativními důsledky ${ }^{18}$.

Z druhé citace je zcela evidentní, že ÚS chápe materiální jádro Ústavy jako pojem totožný s podstatnými náležitostmi demokratického právního státu, Pokud přistoupíme na toto pojetí, vede to k poměrně jednoduchým a jasným důsledkům: podstatné náležitosti demokratického právního státu plní funkci vymezení obsahu toho, co je materiálním ohniskem ústavy, tedy obsahově jsou to totožné pojmy.

Je však možné se na pojem materiálního ohniska ústavy dívat také jinak, než jako na její nezměnitelné části, jak argumentuj Molek (2014, 137 an.) a částečně i Preuss $(2015,36$ an.). Řečeno s využitím metafory Ondřeje Preusse, materiální ohnisko ústavy představuje esenciální obsah společenské smlouvy, tedy ústavy (Preuss 2015, 35). Takový esenciální obsah však nemusí nutně být nezměnitelný. Naopak, podobně jako u jiných smluv, důležité je, aby byly esenciální náležitosti ve smlouvě vymezeny, ovšem existuje mnoho různých způsobů, jak to lze učinit. A také je lze předepsanými způsoby měnit. Pro úplnost je nutno zmínit, že např. Pavlíček tento koncept odmítá jako cizí prvek opřený o prvky nacistické právní filozofie, která směřovala proti parlamentní demokracii a právnímu státu (Pavlíček 2011, 22).

Vzhledem $\mathrm{k}$ tomu, že pojem materiálního ohniska ústavy není v Ústavě nikde výslovně zmíněn, jedná se o pojem zavedený a definovaný odbornou literaturou a judikaturou. Vymezení jeho obsahu je tedy otázkou definiční, resp. rozdílné pohledy na obsah pojmu jsou vlastně sporem o definici. Domnívám se, že v dané situaci se lze na pojem materiálního ohniska legitimně dívat různými způsoby, ovšem z logického hlediska se zdá být vhodnější př́istup Molka, který chápe materiální ohnisko jako samostatný pojem, odlišný od nezměnitelných ustanovení vymezených jako podstatné náležitosti demokratického právního státu.

Zdá se být zbytečné mít dva různé pojmy pro totéž, nebot' to může způsobit spíše zmatení. Logičtější je mít pro dva různé pojmy také dva různé obsahy, a to se myslím Molkovi podařilo. V jeho pohledu se tedy jedná o pojem zásadně odlišný od nezměnitelných ustanovení, který tudíž ani nebude přesně obsahově korespondovat s podstatnými náležitostmi demokratického právního státu, byt' některé principy (suverenita lidu, dělba moci) jsou pro oba pojmy společné.

Myšlenka materiálního ohniska ústavy nabývá podstatně jiného významu $\mathrm{v}$ ústavních systémech, kde není výslovně zakotvena klauzule věčnosti. Tam skutečně může být vymezení materiálního ohniska ústavy jedinou cestou $\mathrm{k}$ ochraně základních ústavních principů. V každé ústavě, pokud má mít určitou vnitřní soudržnost, totiž musejí existovat principy, které označujeme jako materiální jádro či ohnisko (Balog 2014,35). Tyto principy musejí být v ústavě obsaženy, aby daný dokument vưbec bylo

\footnotetext{
${ }^{18}$ Tamtéž.
} 
možné za ústavu označit, a pokud by měly být odstraněny nebo změněny, zasáhlo by to samotnou podstatu ústavy. $\mathrm{V}$ těchto ústavních systémech však zase chybí klauzule věčnosti, resp. nějaká ústavní definice nezměnitelných ustanovení ústavy.

Z toho lze tedy vyvodit, že pojem materiálního jádra (ohniska) je odlišný od klauzule věčnosti i od podstatných náležitostí demokratického právního státu, protože vychází z podstatně odlišného kontextu. V př́ípadě České republiky lze mít za to, že se obsah materiálního jádra (ohniska) v podstatné míře překrývá s obsahem pojmu podstatné náležitosti demokratického právního státu, nejsou to však pojmy totožné.

\section{5. ÚSTAVNÍ IDENTITA ČESKÉ REPUBLIKY}

Podstatné náležitosti demokratického právního státu lze chápat také jako vymezení české ústavní identity (Sobek 2011, 410). Koresponduje to např. s pojetím nezměnitelných ustanovení ústavy v německé odborné literatuře (Kirchhof 2004, § 21, 261 an.; Dreier 1994, č. 15/16, 747; Häberle 1986, 81-108), ale pojem ústavní identity, byt' v poněkud odlišném pojetí, je diskutován také v zemích $\mathrm{s}$ angloamerickým právním systémem (Jacobsohn 2010; Arcioni, Australian Constitutional...). V poslední době je pojem ústavní identity zmiňován stále častěji ${ }^{19}$, zejména v návaznosti na rozhodnutí Spolkového ústavního soudu SRN k Lisabonské smlouvě z roku $2009^{20}$, kde Spolkový ústavní soud rozvinul a aplikoval svou vlastní doktrínu německé ústavní identity, která představuje limit pro další prohlubování evropské integrace (Martí 2013, 17).

Ústavní identitu ČR konečně zmínil i Ústavní soud ČR v rozhodnutí Slovenské důchody XVII, v němž nerespektoval závěry Evropského soudního dvora ve věci C-399/0921 . Tím se ukazuje propojení pojetí podstatných náležitostí demokratického právního státu jako ústavní identity s dalšími rolemi tohoto pojmu v ústavním systému ČR, konkrétně klauzule věčnosti a referenčního rámce přezkumu.

Pojem ústavní identita lze vnímat ve dvou rovinách. Podle první z nich je ústavní identita to, co umožňuje identifikovat daný ústavní režim. Jedná se tedy o určitý soubor prvků či znakủ, které, pokud jsou v ústavním systému př́tomny, znamenají, že se stále jedná o tentýž ústavní systém. Naopak pokud by některý z těchto prvků přestal být př́tomen, bude to znamenat, že se již jedná o odlišný ústavní systém. Ve druhém pojetí ústavní identita vymezuje, kým se lid, který přijal danou ústavu, cítí být. Cílem tedy není ani tak posoudit, zda se stále jedná o tentýž ústavní systém, ale vymezit se, říci kdo jsme. První pojetí může teoreticky být i poměrně technické, založené na určitých ústavních mechanismech (např.

\footnotetext{
${ }^{19}$ Pro přehled různých pojetí viz Rosenfeld (2012, 756 an.).

${ }^{20}$ BVerfG, 2 BvE 2/08 ze dne 30. 6. 2009, (1-421).

${ }^{21}$ Nález Ústavního soudu ze dne 31. 1. 2012, sp. zn. Pl. ÚS 5/12, část VII.
} 
forma vlády, forma státu, systém brzd a rovnovah). Druhé pojetí však ze své podstaty musí být hodnotové.

Pokud nahlédneme pojem podstatné náležitosti demokratického právního státu optikou konceptu ústavní identity, mohou se podstatné náležitosti uplatnit v obou naznačených rovinách. Identifikují hlavní znaky ústavního systému ČR, ve smyslu zjištění, zda i po provedení nějakých ústavních změn se jedná stále o tentýž ústavní systém, ale také vymezují hodnotový rámec Ústavy ČR.

Při úvahách o vztahu ústavní identity a podstatných náležitostí demokratického právního státu je podstatné, zda pojem podstatných náležitostí použitý v Ústavě ČR je odkazem na nějaký univerzální princip, takže by jej bylo možné vymezit pouze na základě univerzálních, všeobecně uznávaných standardů, nebo zda se jedná o projev specificky české ústavní identity. Domnívám se, že řešením je propojení těchto dvou přístupů. Univerzální prvky představují jen část pojmu podstatných náležitostí demokratického právního státu a odrážejí skutečnost, že Česká republika se identifikuje jako součást společenství států založeného na respektování těchto principů. Samy o sobě však k jejich definici nestačí, nebot' Česká republika má také svou vlastní jedinečnou ústavní identitu, která vychází z naší historické zkušenosti, společenských podmínek, kultury a tradice, a odráží se ve volbách, které ústavodárce učinil při formování ústavního systému ČR. Shrnuto to tedy znamená, že pojem podstatné náležitosti demokratického právního státu má určitou univerzální složku, která odráží vnější vztahy a ukotvení ČR v rámci mezinárodního společenství (tedy v čem se s ostatními státy shodneme), a specifickou složku, která je pro ČR jedinečná a od ostatních států ji odlišuje.

\section{HODNOTOVÉ UKOTVENÍ ÚSTAVY ČR}

Z vymezení demokratického právního státu v judikatuře Ústavního soudu je patrné, že pro Ústavní soud jeho důležitou součást představují i hodnotové prvky. Ústava jako základní právní dokument státu vymezuje nejen konkrétní pravidla, ale také obecnější principy a zcela nejobecněji hodnoty, které stát svou činností sleduje. Většina obecných principů je $\mathrm{v}$ českém právním řádu obsažena právě v Ústavě, přestože některé, zpravidla dílčí, lze nalézt i v zákonech. Hodnoty jsou však takřka výhradně obsaženy jen v Ústavě, někdy dokonce pouze v jejích nenormativních částech (preambule). Z toho, jak detailně analyzují např. J. Přibáń (2007) nebo N. Luhmann (1995, 470 an.), pramení specifičnost ústavního práva, které stojí na pomezí politiky a práva, obsahuje kombinaci pravidel, principů a hodnot, zakotvuje často nenormativní ustanovení, a také je často zachyceno v symbolické podobě (napřs. sliby ústavních činitelů).

$\mathrm{Z}$ tohoto pohledu tedy ústavní právo plní roli nejen základu celého právního řádu, tzv. základní normy, a vrcholu pyramidy právních norem, ale díky principu prozařování působí vertikálně na všech úrovních jako interpretační základ všech 
odvětví práva. Konkrétním projevem tohoto mechanismu je např. princip ústavně konformního výkladu či incidentní kontrola ústavnosti. Ústavní právo je pro tuto funkci velice dobře vybaveno, nebot' obsahuje neobvykle velké množství principů a hodnot na poměrně omezeném prostoru, a to v poměrně přehledné struktuře připravené $\mathrm{k}$ praktickému použití.

Ústavní soud z toho vyvozuje, že ústavní systém je postaven na systému objektivních hodnot ${ }^{22}$, které jsou provázány se základními principy, z nichž některé jsou nezměnitelné. Protože se jedná o objektivní hodnoty, musí je všechny orgány svou činností naplňovat a v souladu s nimi vykládat ústavu. Ze základních hodnot, jako je lidská důstojnost, spravedlnost či úcta státní moci k lidským právům, se odvíjí konkrétnější ústavní principy, a to jak v oblasti základních práv, tak v oblasti organizace státní moci (Morawska 2003, 68).

Právo je nástrojem $\mathrm{k}$ řešení konfliktů soupeřících hodnot. Právo má výhodu v tom, že ačkoliv reflektuje společenské hodnoty, může se také vyvíjet, stejně jako se vyvíjejí hodnoty, a flexibilně reagovat. Může dokonce předběhnout společenské hodnoty a, tam kde je to potřebné, vyprovokovat nebo propagovat změnu. Interakce mezi právem a společenskými hodnotami je bezpochyby složitý komplexní proces, kde je složité jasně identifikovat kauzalitu. Výhodou práva je i to, že se vyvíjí pragmaticky, reakcemi v konkrétních případech a uplatnění problemsolving prístupu (Jacobs 2007, 77).

Pokud zvážíme všechny uvedené role, které může pojem podstatných náležitostí demokratického právního státu v ústavním systému ČR plnit, je podle mne nutné odlišit funkci klauzule věčnosti a na to navazující funkci referenčního rámce přezkumu od zbylých tř́i funkcí, tedy materiálního jádra, hodnotového zakotvení ústavy a ústavní identity. Funkce klauzule věčnosti a referenčního rámce jsou úzce propojeny, jsou hlavním smyslem zakotvení čl. 9 odst. 2 v Ústavě ČR a mají konkrétní právní důsledky. Ostatní tři funkce hrají roli spíše filozofickoteoretickou, jsou jakýmsi vedlejším efektem existence čl. 9 odst. 2 Ústavy ČR, a nemají tudíž konkrétní důsledky pro text Ústavy ČR. Jsou však podstatné pro hodnotové zakotvení systému, pro řešení složitých hodnotových otázek a v tomto smyslu pro rozhodovací činnost Ústavního soudu.

\section{OBSAHOVÉ VYMEZENÍ PODSTATNÝCH NÁLEŽITOSTÍ DEMOKRATICKÉHO PRÁVNÍHO STÁTU}

Vymezení konkrétního obsahu podstatných náležitostí demokratického právního státu je obtížný úkol, protože obsah demokratického právního státu, coby nadřazeného, obecnějš́ího pojmu, se převážně skládá z principů, tedy určitých obecných cílů, který jsou naplňovány na škále, tedy do určité míry, nikoliv bud’to

${ }^{22}$ Nález Ústavního soudu ze dne 21. 12. 1993, sp. zn. Pl. ÚS 19/93, část A. 
absolutně nebo vůbec v bipolární modalitě ANO-NE, jako by tomu bylo u pravidel $^{23}$. Rovněž je nutné si uvědomit, jak uvádí Dworkin $(2013,8)$ že i když na některých konkrétních principech obsažených $\mathrm{v}$ širším principu právního státu existuje $\mathrm{v}$ zásadě shoda, vzhledem $\mathrm{k}$ povaze právního státu jako principu nelze ř́íci, že by porušením některého z nich daný stát přestal být právním státem. Podle Dworkina bychom se tedy neměli ptát, zda daný stát je právním státem, ale spíše do jaké míry splňuje jeho podmínky nebo jak moc je porušuje. Obdobně to platí i u principů demokracie - $\mathrm{i}$ její předpoklady jsou splňovány v různých společnostech v různé míře, stejně jako demokracie samotná (Cohen 1971, 101). Ve smyslu volební demokracie (minimalistické pojetí) např. Rusko demokracií je, zatímco ve smyslu liberální demokracie nikoliv (Diamond 2003, 34). V tomto smyslu je tedy problematické přesně vymezit nějakou jednoznačnou hranici, při jejímž překročení by už Česká republika přestala být demokratickým právním státem, a tím vymezit podstatné náležitosti demokratického právního státu.

Exaktně a s konečnou platností vymezit podstatné náležitosti demokratického právního státu není vhodné rovněž proto, že ze způsobu jejich ústavního zakotvení vyplývá, že mají být pojmem alespoň relativně otevřeným, který se bude postupně vyvíjet díky výkladu zejména Ústavního soudu ČR ${ }^{24}$. Na základě dosavadní judikatury Ústavního soudu ČR však lze vyvodit alespoň některé prvky, které lze nezpochybnitelně do rámce podstatných náležitostí demokratického právního státu zahrnout.

V prvé řadě se jedná o esenciální obsah základních práv a svobod ${ }^{25}$. V pojetí českého ústavního pořádku (v návaznosti na českou ústavní identitu) existuje u téměř všech ústavně zaručených práv ${ }^{26}$ určité neomezitelné jádro, o něco užší u práv sociálních, poněkud širší u práv ostatních. Existence tohoto jádra brání úplnému popření daného ústavně zaručeného práva. Co je oním jádrem, tedy esenciálním obsahem nebo slovy čl. 4 odst. 4 Listiny podstatou a smyslem práva, je nutno nejprve určit obecně z pohledu smyslu zakotvení daného práva, a poté zkoumat, zda tento esenciální obsah byl zasažen v konkrétní situaci, když dojde k přezkumu ústavnosti omezení daného práva. Při určení, zda jde o zásah do esenciálního obsahu, je nutné zvážit, zda se dotýká důvodu nebo účelu, proč ústavodárce dané právo v Listině zakotvil, a zda dotčený obsah má povahu principu nebo pravidla. Jako pomocné kritérium lze zohlednit, zda nedošlo ke kolizi s esenciálním obsahem jiných práv.

${ }^{23}$ Pro odlišení principů a pravidel viz Dworkin (1967, roč. 35, č. 1, s. 14-46), pro aktuální reflexi vývoje viz Brożek (2012, 205-226); na př́kladu základních práv demonstruje rozdíly Alexy $(2009,44)$. O pravidlech a principech a k povaze základních práv jako principů viz také Dworkin (1977).

${ }^{24}$ Nález Ústavního soudu ze dne 29. 5. 1997, sp. zn. III. ÚS 31/97, část II.

${ }^{25}$ Podrobněji viz Tomoszek (2015a, 3-15).

${ }^{26} \mathrm{~S}$ možnou výjimkou např. u zákazu diskriminace. 
Důsledky plynoucí z ochrany esenciálního obsahu základních práv se týkají zejména posuzování ústavnosti omezení základních práv. Vymezení esenciálního obsahu je klíčem $\mathrm{k}$ určení, zda bude u sociálních práv použit test racionality nebo proporcionality, u ostatních práv pak určení, zda je omezení vůbec př́ípustné. Ve vazbě na čl. 9 odst. 2 Ústavy lze vyvodit, že esenciální obsah základních práv a neomezitelné jádro sociálních práv představuje zároveň podstatné náležitosti demokratického právního státu, a nemůže být tedy omezeno ani ústavním zákonem nebo v důsledku mezinárodních závazků.

Při identifikaci esenciálního obsahu základního práva v konkrétní situaci je nutné zejména zvážit:

a. zda se omezení daného práva dotýká důvodu nebo účelu, proč ústavodárce dané právo $\mathrm{v}$ Listině zakotvil,

b. zda dotčený obsah má povahu principu nebo pravidla,

c. jako pomocné kritérium lze zohlednit, zda nedošlo ke kolizi s esenciálním obsahem jiných práv.

Tyto postupy lze analogicky aplikovat i do jiných oblastí principů demokratického právního státu, než je ochrana základních práv, tedy zejména jeho formálních, organizačních a procesních prvků, jako jsou princip právní jistoty, dělby moci a další. Znamenalo by to vždy především potřebu určit účel nebo důvod, proč je daný princip $\mathrm{v}$ ústavním systému zakotven, a identifikovat tu část daného principu, která má povahu ostrého pravidla, které se bud' uplatní, nebo neuplatní (ANO-NE). Porušením podstatných náležitostí demokratického právního státu je však nejen takový zásah, který porušuje striktní pravidlo obsažené v některé součásti demokratického právního státu, ale i takový zásah, který by nějaký takový princip úplně popřel či vyprázdnil.

Z pohledu podstatných náležitostí demokratického právního státu by v tomto směru bylo možné dát př́íklad suverenity lidu. Suverenita lidu se v ústavním systému projevuje různými způsoby a lze z ní vyvodit řadu sub-principů, které jsou naplňovány $\mathrm{v}$ určité míré. Nelze asi úplně přsesně porovnat míru legitimity různých ústavních orgánů a z toho vyvozovat, který z nich lépe projevuje přání suveréna. Pokud chápeme jako součást principu suverenity lidu také právo na odpor, je otázka, za jakých přsesně podmínek už ho lid může uplatnit, př́ípadně co je důsledkem toho, že lid vyhodnotí tyto podmínky špatně a uplatní právo na odpor tehdy, kdy to ještě není možné.

Domnívám se ale, že princip suverenity lidu obsahuje také některé ostrá pravidla, která bud' platí, nebo neplatí. Jedním z nich je, že veškerá moc ve státě musí být odvozena od lidu, tedy že nemůže existovat státní orgán, který by s lidem nebyl spojen legitimačním řetězcem. S tím také souvisí princip vlády na čas - asi nelze přesně stanovit, zda vhodné funkční období pro poslance Poslanecké sněmovny je čtyři roky nebo pět let, ale je jasné, že doživotní mandát všech poslanců by byl s principem vlády na čas $\mathrm{v}$ rozporu. 
Dalším důležitým kritériem, které je nutné zvážit, je skutečnost, že jednotlivé součásti podstatných náležitostí demokratického právního nemohou být mezi sebou v rozporu, protože to by přivedlo ústavní systém do neřešitelné situace. To je relevantní zejména $\mathrm{z}$ toho důvodu, že některé součásti demokratického právního státu jsou ve vzájemném napětí nebo konfliktu, vyvažují se, aby byla v ústavním systému zajištěna rovnováha. Ty složky, které lze do tohoto vyvažování zahrnout, mezi podstatné náležitosti demokratického právního státu zpravidla nemohou patřit.

Ř́kám-li zpravidla, narážím tím na problém systémových změn. Jak již bylo uvedeno, některé změny samy o sobě problematické nejsou, ovšem mohou se takovými stát ve spojení s jinými změnami, a naopak existují i změny, které by samy o sobě byly porušením podstatných náležitostí demokratického právního státu, ovšem pokud by byly provedeny v rámci komplexní novely ve spojení s úpravou některých dalších součástí ústavního systému, byly by přijatelné.

$\mathrm{Z}$ toho vyplývá, že je nutné $\mathrm{k}$ uplatnění čl. 9 odst. 2 Ústavy přistupovat $\mathrm{v}$ plném kontextu změn, které posuzujeme, a nikoli odděleně. $Z$ pohledu vymezení obsahu podstatných náležitostí to nepředstavuje problém pro vymezení těch složek, jejichž změna sama o sobě by byla porušením čl. 9 odst. 2 Ústavy - lze např. uvést, že při komplexní revizi Ústavy ČR by tato změna nemusela být vyloučena. Ovšem u těch změn, kde jejich rozpor s čl. 9 odst. 2 Ústavy ČR vyplývá až ze souhrnu účinků jednotlivě akceptovatelných opatření, je zcela vyloučeno dopředu říci, jaké prresně kombinace změn by představovaly porušení podstatných náležitostí demokratického právního státu, resp. je možné uvést nějaké př́klady, ale konkrétní posouzení vždy bude záviset na konkrétní situaci a jejím posouzení Ústavním soudem ČR.

Při snaze o hledání inspirace v oblasti ochrany základních práv se také nabízí otázka, zda při uplatnění čl. 9 odst. 2 Ústavy ČR lze použít test proporcionality. Již ve vztahu k nálezu ve věci Melčák se tato otázka řešila jak př́mo v nálezu ${ }^{27}$, tak i v odborné literaturere ${ }^{28}$. V návaznosti na závěry z podkapitoly věnované esenciálnímu obsahu základních práv se domnívám, že test proporcionality může při posouzení, zda došlo $\mathrm{k}$ zásahu do podstatných náležitostí demokratického právního státu, dát určité vodítko, a to v tom smyslu, že kde je možné vyvažovat, nejde ještě o zásah do podstatných náležitostí. Svůj dřívější závěr (Tomoszek 2010b, 8-9) o možnosti využití testu proporcionality pro přezkum ústavních zákonů však musím opravit $\mathrm{v}$ tom směru, že jeho využití pro účel zhodnocení, zda je změnou Ústavy C̆R zasaženo do podstatných náležitostí demokratického právního státu, není možné. Podstatné náležitosti demokratického právního státu totiž mají

${ }^{27}$ Nález Ústavního soudu ze dne 10. září 2009, sp. zn. Pl. ÚS 27/09, část VI/a, viz též odlišné stanovisko soudce Vladimíra Kůrky k tomuto nálezu, bod 16, a odlišné stanovisko soudce Jana Musila k tomuto nálezu, bod 38.

${ }^{28}$ Preuss $(2015,186)$, Šimíček (2009, 233), Tomoszek (2010b, 6-9), ve srovnávacím kontextu viz též Roznai (2014, 204-205). 
povahu pravidel, nikoli principů, a rovněž sledují v ústavním systému tak zásadní účel, že jeho popření nelze vyvážit dosažením jiného cíle, principu nebo hodnoty (Roznai 2014, 204-205).

Při pohledu na to, jak širokým způsobem je v judikatư̌e ÚS chápán pojem demokratický právní stát, se nabízí otázka, které z množství zmíněných principů představují podstatné náležitosti demokratického právního státu, tedy jeho jádro. Odpověd' je třeba hledat na prvním místě v judikatuře ÚS.

Lze se setkat s poměrně obecnou shrnující definicí podstatných náležitostí demokratického právního státu:

Vůdčím principem je nepochybně zásada nezadatelných, nezcizitelných, nepromlčitelných a nezrušitelných základních práv a svobod jednotlivců, rovných v důstojnosti a právech; $\mathrm{k}$ jejich ochraně je budován systém opírající se o zásady demokracie, svrchovanosti lidu, dělby moci, respektující zejména zmíněné materiální pojetí právního státu. Tyto zásady nejsou dotknutelné ani formálněprávně souladně provedenou změnou Ústavy, protože mnohé z nich jsou zjevně přirozenoprávního původu, a stát tedy není jejich poskytovatelem, ale může a musí je - jako ústavní stát - pouze zaručovat a chránit ${ }^{29}$.

Takovéto vymezení ovšem pro potřeby vymezení referenčního rámce přezkumu není prŕliš vhodné, nebot' obsahuje velmi obecné principy, jako např. dělba moci, z nichž podstatné náležitosti budou tvořit jen některé dílčí složky, jak již bylo naznačeno výše. Tuto obecnou definici je tedy nutné konkretizovat do podoby konkrétních prvků. V judikatuře ÚS můžeme nalézt i takovéto konkrétní vymezení. Začít můžeme u určitých procesních principů směřujících k omezení státní moci a ochraně práv jednotlivce:

[...] princip, podle něhož lze státní moc vůči jednotlivci a jeho autonomní sféře (včetně autonomních projevů volních) uplatňovat pouze $\mathrm{v}$ př́ípadech, kdy jednání jednotlivce porušuje výslovně formulovaný zákaz upravený zákonem. Takový zákaz však musí reflektovat toliko požadavek, spočívající v zabránění jednotlivci v zásazích do práv třetích osob a v prosazení veřejného zájmu, je-li legitimní a proporcionální takovému omezení autonomního jednání jednotlivce. Tento princip je pak třeba chápat jako esenciální náležitost každého demokratického právního státu (čl. 1 odst. 1 Ústavy) ${ }^{30}$.

\section{V jiném nálezu ÚS vyjádřil podobnou myšlenku jinými slovy:}

[...] jedním z esenciálních znaků demokratického právního státu je princip přiměřenosti, který zejména předpokládá, že opatření omezující základní práva či svobody nesmějí svými negativními důsledky přesáhnout klady, které představuje veřejný zájem na těchto opatřeních. K omezení základních práv či svobod sice může zcela výjimečně dojít i v případě jejich kolize s některým z veřejných statků (veřejný zájem); podstatná je však v této souvislosti maxima, podle které základní právo či svobodu lze omezit pouze $\mathrm{v}$ případě mimořádně silného a řádně odůvodněného veřejného zájmu, při pečlivém šetření podstaty a smyslu omezovaného základního práva ${ }^{31}$.

\footnotetext{
${ }^{29}$ Nález Ústavního soudu ze dne 26. listopadu 2008, sp. zn. Pl. ÚS 19/08, odst. 93.

${ }^{30}$ Nález Ústavního soudu ze dne 10. března 2015, sp. zn. II. ÚS 2050/14, odst. 26.

${ }^{31}$ Nález Ústavního soudu ze dne 12. března 2008, sp. zn. Pl. ÚS 83/06, odst. 184.
} 
S tímto pohledem úzce souvisí, že podle ÚS ,,[a]utonomi[i] vůle jednotlivce jako základní právo a zároveň princip je pak třeba chápat jako esenciální náležitost demokratického právního státu“ ${ }^{\text {“32. }}$. Ve vztahu k procedurálním nástrojům ochrany základních práv vyjádřil ÚS závěr, že:

[z] ústavní maximy dle čl. 9 odst. 2 Ústavy neplynou konsekvence toliko pro ústavodárce, nýbrž i pro Ústavní soud. V nepř́ípustnosti změny podstatných náležitostí demokratického právního státu je obsažen i pokyn Ústavnímu soudu, dle kterého žádnou novelu Ústavy nelze interpretovat $\mathrm{v}$ tom smyslu, že by jejím důsledkem bylo omezení již dosažené procedurální úrovně ochrany základních práv a svobod ${ }^{33}$.

Zároveň se zde ukázalo, že jedním z možných prostředků ochrany podstatných náležitostí demokratického právního státu je i ústavně konformní výklad změn Ústavy ČR, resp. výklad konformní s čl. 9 odst. 2 Ústavy ČR ${ }^{34}$.

Další oblastí je dělba moci, kterou samotnou Ústavní soud chápe jako součást podstatných náležitostí demokratického právního státu ${ }^{35}$, stejně jako jednu z jejích klíčových součástí - princip nezávislého soudnictvíi ${ }^{36}$. Na to navazuje princip z oblasti právní jistoty, kterým je zákaz libovůle při soudním rozhodování:

[...] nemá-li se sám Ústavní soud jako ústavní orgán, tj. orgán veřejné moci, dopouštět libovůle, jejímuž zákazu je sám také podroben, nebot' i Ústavní soud, či právě on, je povinen respektovat rámec ústavního státu, v němž je výkon libovůle orgánům veřejné moci striktně zapovězen, musí se cítit vázán svými vlastními rozhodnutími, která může svou judikaturou překonat jen za určitých podmínek. Tento postulát lze přitom charakterizovat jako podstatnou náležitost demokratického právního státu (čl. 1 odst. 1 ve spojení s čl. 9 odst. 2 Ústavy) ${ }^{37}$.

Z pohledu vertikální dělby moci považuje Ústavní soud za klíčovou složku ústavní garance práva obcí na samosprávu ${ }^{38}$, a zmiňuje, že některými autory jsou dokonce řazeny mezi podstatné náležitosti demokratického právního státu. Konkrétně se odkazuje na komentář Podhrázského, podle nějž „lze toto právo ve svých základních obrysech mezi uvedené materiální jádro nepochybně řadit“ (Podhrázský 2010, 140 (čl. 8 Ústavy)). Podhrázský se dále odkazuje na Mikuleho, který to, že v České republice bude uplatňován princip územní samosprávy, řadí mezi podstatné náležitosti demokratického právního státu a odstoupení od tohoto principu považuje s odkazem na čl. 9 odst. 2 Ústavy ČR za ústavně nepř́ípustnou změnu (Mikule 2007, 64 (čl. 8)).

${ }^{32}$ Nález Ústavního soudu ze dne 24. července 2007, sp. zn. I. ÚS 557/05, odst. 27, později tento názor ÚS potvrdil v nálezu ze dne 26. záŕí 2013, sp. zn. III. ÚS 3333/11, odst. 31.

${ }^{33}$ Nález Ústavního soudu ze dne 25. června 2002, sp. zn. Pl. ÚS 36/01, část VII.

${ }^{34}$ Nález Ústavního soudu ze dne 10. září 2009, sp. zn. P1. ÚS 27/09, část IV.

${ }^{35}$ Usnesení Ústavního soudu ze dne 27. února 2007, sp. zn. IV. ÚS 606/06.

${ }^{36}$ Nález Ústavního soudu ze dne 10. července 2014, sp. zn. Pl. ÚS 28/13, odst. 61.

${ }^{37}$ Nález Ústavního soudu ze dne 11. června 2003, sp. zn. Pl. ÚS 11/02, část V. 2., tento názor později ÚS potvrdil např. v nálezu ze dne 19. června 2014, sp. zn. III. ÚS 980/13, odst. 29. Tento závěr potvrzuje i Holländer $(2012,329)$.

${ }^{38}$ Nález Ústavního soudu ze dne 2. dubna 2013, sp. zn. Pl. ÚS 6/13, odst. 27. 
Hodnotovou složku podstatných náležitostí demokratického právního státu vymezil ÚS takto:

Byla-li státní správa v pojetí formálního právního státu př́ísně vázána na zákon ve formálním smyslu, vyznačuje se materiální ústavní stát svým přitakáním nadpozitivním hodnotám (ve smyslu čl. 9 odst. 2 Ústavy České republiky), jakými jsou lidská důstojnost, svoboda, spravedlnost, které představují podstatné náležitosti demokratického právního státu. Respekt a ochrana lidské důstojnosti a svobody je nejvyšším a nejobecnějším účelem práva ${ }^{39}$.

Ústavní soud mezi podstatné náležitosti demokratického právního státu zařadil také princip právní jistoty ${ }^{40}$. Jak bude zmíněno dále, takto obecně vymezený princip nesplňuje kritéria podstatných náležitostí demokratického právního státu, je tedy nutné dále konkretizovat, co přesně z obsahu principu právní jistoty představuje její podstatné náležitosti. Takovou konkretizaci provedl Ústavní soud např. v nálezu v kauze Melčák, kde za složky podstatných náležitostí demokratického právního státu z oblasti právní jistoty označil princip obecnosti ústavního zákona ${ }^{41}$ a zákaz retroaktivity ústavního zákona ${ }^{42}$.

V citovaném rozhodnutí Ústavní soud zmínil i další součásti podstatných náležitostí demokratického právního státu, přičemž se odkázal na stanoviska doktrinární, dle nichž k podstatným náležitostem demokratického právního státu ve smyslu čl. 9 odst. 2 a 3 Ústavy patří ,především svrchovanost lidu a principy obsažené v čl. 5 a 6 Ústavy a přirozenoprávní ustanovení Listiny základních práv a svobod, která zakládají ústavní právo na odpor (čl. 23 Listiny) “43 , resp. vyjádřeno jinak jsou tyto náležitosti „koncentrovány v několika článcích I. hlavy Ústavy a I. a V. hlavy Listiny a slavnostně prohlášeny v Preambuli Ústavy“44. Mezi principy organizačního charakteru související spíše s demokratickou složkou principů demokratického právního je rozhodně nutno podle Ústavního soudu, ve shodě $\mathrm{s}$ odbornou literaturou ${ }^{45}$, považovat i základní principy volebního práva ${ }^{46}$.

Opět je však nutno podotknout, že vzhledem k obecnosti tohoto vymezení není zcela jasné, které přesně součásti uvedených principů mezi podstatné

\footnotetext{
${ }^{39}$ Nález Ústavního soudu ze dne 29. února 2008, sp. zn. II. ÚS 2268/07, odst. 41.

${ }^{40}$ Nález Ústavního soudu ze dne 6. června 2001, sp. zn. Pl. ÚS 46/2000 (závěrečná část odůvodnění).

${ }^{41}$ Nález Ústavního soudu ze dne 10. září 2009, sp. zn. Pl. ÚS 27/09, část VI. a. Shodně Holländer $(2005,340)$.

${ }^{42}$ Nález Ústavního soudu ze dne 10. záŕí 2009, sp. zn. Pl. ÚS 27/09, část VI. b. Shodně tamtéž, 344.

${ }^{43}$ Pavlíček, Hřebejk (1994, 55), citováno dle nálezu Ústavního soudu ze dne 29. května 1997, sp. zn. III. ÚS 31/97, část II. Podobně také Hendrych, Svoboda a kol. (1997, 10).

${ }^{44}$ Gerloch, Hřebejk, Zoubek (1996, 84), citováno dle nálezu Ústavního soudu ze dne 29. května 1997, sp. zn. III. ÚS 31/97, část II.

${ }^{45}$ Podle Filip (1997-1998, 132): ,problematika volebního období je communis opinio doctorum podstatnou náležitostí demokratického vládního systému“.

${ }^{46}$ Nález Ústavního soudu ze dne 10. záŕí 2009, sp. zn. Pl. ÚS 27/09, část IV., a to s odkazem na nález ÚS ze dne 6. 2. 2001, sp. zn. Pl. ÚS 42/2000.
} 
náležitosti skutečně patř̌i. Domnívám se, že např. u principu suverenity lidu by za podstatnou náležitost bylo možné označit princip, že každý státní orgán musí být s lidem spojen legitimačním řetězcem a že nemůže existovat orgán, který svou legitimitu neodvozuje (alespoň zprostředkovaně) od lidu.

Ve vztahu k dělbě moci uvádí konkrétní př́iklad Jirásková, podle níž je nutné za podstatnou náležitost demokratického právního státu považovat, že jiný subjekt stanoví ústavní pravidla a jiný orgán je povolán stanovenými prostředky uskutečňovat ochranu těchto pravidel, tedy $\mathrm{v}$ rámci dělby moci musí dojít k rozdělení moci mezi tvůrce ústavních předpisů a orgány ochraňující jejich dodržování (Jirásková 2011, 371).

Tím v podstatě plynule přecházíme $\mathrm{k}$ přehledu toho, jak jsou podstatné náležitosti demokratického právního státu vymezeny v odborné literatuře.

Jirásková jako podstatné náležitosti demokratického právního státu dále uvádí republikánskou státní formu, svrchovanost a jednotu státu, ústavně stanovenou dělbu moci, uznání svobody a rovnosti lidí v důstojnosti a v právech, svrchovanost lidu, princip sebeomezení státu, odpovědnost a demokratickou legitimitu moci založenou na svobodných volbách, ale také to, že každý funkcionář v demokratickém státě podléhá kontrole. Mezi podstatné náležitosti zahrnuje i další zásady obsažené zejména v čl. 5 a 6 Ústavy, tedy pluralitní demokratický politický systém (Jirásková 2011, 372).

Poměrně široká shoda panuje na zařazení samotného ustanovení čl. 9 odst. 2 Ústavy ČR mezi podstatné náležitosti demokratického právního státu, což je ostatně nanejvýš logické (Holländer 2005, 331; Syllová 2007, 71 (čl. 9); Šimíček 2010, 159 (čl. 9 odst. 2 Ústavy)). Nemělo by valného smyslu zakotvit nezrušitelnost některých základních principů, kdyby ji bylo možné obejít zrušením ustanovení, v němž je zakotvena.

Naopak rozdílné názory lze zaznamenat $\mathrm{v}$ otázce, zda podstatnou náležitostí demokratického právního státu je republikánská státní forma. Např. Jirásková, jak již bylo zmíněno, ji mezi podstatné náležitosti řadí (Jirásková 2011, 372), naopak Syllová (2007, 72 (čl. 9)) nebo Šimíček (2010, 159 (čl. 9 odst. 2 Ústavy)) nikoli.

$\mathrm{Z}$ dalších autorů lze zmínit Wintra, který mezi podstatné náležitosti demokratického právního státu řadí volby na základě všeobecného, rovného a př́imého volebního práva, pluralitu politických stran, nezávislost soudnictví, samosprávu obcí a základní práva a svobody (Wintr 2013,31).

Patrně nejširší katalog podstatných náležitostí demokratického právního státu uvádí Šimíček (2010, 158-159 (čl. 9 odst. 2 Ústavy)), podle nějž nedotknutelné ústavní principy zahrnují:

a. svrchovanost lidu (čl. 2 Ústavy ČR),

b. zakotvení a ochranu základních práv a svobod,

c. panství práva (vázanost právním řádem),

d. volnou soutěž politických stran (čl. 5 Ústavy ČR),

e. rozhodování většiny se současným respektováním práv menšiny (čl. 6), 
f. základní principy volebního práva,

g. vládu na čas,

h. dělbu státní moci,

i. nezávislost soudů a soudců (čl. 81 a 82 Ústavy ČR),

j. právo na územní samosprávu (zejm. čl. 8 Ústavy ČR), ovšem pouze v základních rysech, nikoli např. ve smyslu dvoustupňovosti samosprávného uspořádání anebo fixního počtu vyšších územních samosprávných celků,

k. nezměnitelnost materiálního ohniska ústavního pořádku (čl. 9 odst. 2 Ústavy (̌R).

Za obecný problém uvedených snah o vymezení obsahu podstatné náležitosti demokratického právního státu lze považovat, že je tento obsah vymezen pomocí poměrně obecných principů, jako např. dělba moci, nezávislost soudů, obecné principy volebního práva apod. Za prvé se tyto principy v zásadě neliší od principů použitých pro vymezení pojmu demokratický právní stát $-\mathrm{z}$ toho by bylo možné vyvodit, že pojem podstatné náležitosti demokratického právního státu je vymezen jako výběr principů, ze kterých se skládá pojem demokratický právní stát. S tím nesouhlasím, nebot' pojem podstatné náležitosti podle mne znamená, že je nutno z principů demokratického právního státu chránit jejich podstatu a smysl, či esenciální obsah, nikoli to, že bychom z nich měli vybrat některé, které považujeme za obzvlášt' významné, a tyto principy by v celém svém obsahu představovaly podstatné náležitosti demokratického právního státu. To by znamenalo, že některé z principů demokratického právního státu nejsou mezi jeho podstatnými náležitostmi zahrnuty vůbec, tedy že by bylo možné je úplně odstranit. Jako př́iklad lze uvést předvídatelnost práva, ochranu nabytých práv, zákaz libovůle apod. Tento př́stup je však podle mne neakceptovatelný.

Druhým možným vysvětlením by bylo, že mezi podstatné náležitosti demokratického právního státu výše uvedené principy (jako např. dělba moci, nezávislost soudů apod.) patří v tom smyslu, že je není možné úplně popřít, zrušit nebo odstranit. To však podle mne platí o všech principech, které jsou součástí pojmu demokratický právní stát. Čl. 9 odst. 2 Ústavy ČR je podle mne nutno chápat tak, že u každého z principů demokratického právního státu je nutné zachovat jeho esenciální obsah, tedy jeho podstatné náležitosti. Tedy ani druhé vysvětlení se nezdá být přijatelné, nebot' podle něj by opět některé principy demokratického právního státu, které v uvedených výčtech nejsou zmíněny, bylo možné zcela popř́t. Jediný způsob, jak by bylo možné uvedené definice smysluplně vyložit, je podle mého názoru ten, že to nejsou taxativní, nýbrž demonstrativní výčty (což ostatně většina autorů výslovně zmiňuje nebo to alespoň z kontextu vyplývá), a že ochrana se uváděných principů týká $\mathrm{v}$ tom smyslu, že nemohou být úplně popřeny nebo zrušeny.

Tyto závěry jsou sice samy o sobě správné, ovšem jde podle mne o zjednodušující přístup, který odráží jen část problémů, jimž můžeme z pohledu čl. 9 odst. 2 Ústavy ČR čelit. Domnívám se, že není príiliš pravděpodobná situace, že 
by měl být přijat ústavní zákon, který by některý z uvedených principů, např̀. dělbu moci, úplně popřel nebo vypustil. Spíše považuji za pravděpodobné, že může dojít $\mathrm{k}$ přijetí ústavního zákona, který do některého z principů demokratického právního státu zasáhne tak, že nebude jasně zřejmé, zda byl či nebyl zasažen jeho esenciální obsah. $Z$ toho podle mne vyplývá nutnost vymezit u každého principu demokratického právního státu, co z něj je v diskreci ústavodárce, a co je mimo ni, tedy co představuje nezměnitelné jádro daného principu.

Představme si např. takovou změnu Ústavy ČR, která by úplně zrušila institut kontrasignace rozhodnutí prezidenta republiky. Jedná se nepochybně o zásah do principu dělby moci, konkrétně systému brzd a rovnovah, ovšem je otázka, zda se jedná o takový zásah, který je porušením podstatných náležitostí demokratického právního státu. Musí v ústavním systému ČR nutně být zakotven institut kontrasignace? Zcela jistě by se jednalo o změnu formy vlády, to ovšem samo o sobě neznamená, že by ČR již nebyla demokratickým právním státem. Domnívám se však, že by tento zásah byl v rozporu s esenciálním obsahem principu odpovědnosti veřejné moci, nebot' vzhledem k ústavně zakotvené neodpovědnosti prezidenta ČR (resp. velmi omezené odpovědnosti) by zrušení kontrasignace znamenal, že za některá rozhodnutí prezidenta republiky by nebyl odpovědný nikdo.

Vymezení podstatných náležitostí demokratického právního státu se tak jeví jako spíše kazuistický úkol, který by měl plnit Ústavní soud. Ostatně již nyní lze zaznamenat, že ve své judikatuře některé velmi konkrétní principy, které chápe jako podstatné náležitosti demokratického právního státu, vymezil - např. obecnost ústavního zákona, zákaz retroaktivity ústavního zákona, zákaz libovưle projevující se jako povinnost (nejen) Ústavního soudu neodchylovat se bez přesvědčivých důvodů od svých dřívějších rozhodnutí apod.

Pokud bychom tímto způsobem přistoupili k vymezení esenciálního obsahu principu odpovědnosti veřejné moci, lze jako podstatné náležitosti demokratického právního státu chápat zejména následující tyto prvky:

a. právní odpovědnost orgánu vedoucího jakýkoliv právní proces ve formě opravných prostředků proti rozhodnutí tohoto orgánu,

b. soudní kontrola ústavnosti právních předpisů jako kontrola výsledků činnosti moci zákonodárné,

c. existence správního soudnictví, tedy soudní kontroly rozhodování orgánů výkonné moci,

d. existence odpovědnosti státu za pochybení při výkonu státní moci, včetně náhrady škody způsobené nezákonným rozhodnutím nebo postupem,

e. existence individuální ústavní stížnosti jako prostředku odpovědnosti státu za zajištění základních práv a svobod jednotlivce,

f. politickou odpovědnost vlády Poslanecké sněmovně,

g. ústavněprávní odpovědnost přímo voleného prezidenta republiky za ústavní delikt, 
h. kontrasignace převážné většiny politických rozhodnutí prezidenta republiky tak, aby se minimalizoval počet kompetencí, za jejichž výkon není nikdo odpovědný.

U dělby moci existuje jen poměrně malé jádro představující podstatné náležitosti, protože konkrétní provedení horizontální i vertikální dělby moci připouští velké množství odlišných variant (Aulehner 2011, 212). V souladu s již formulovaným principem existence univerzálních i národně-specifických prvků podstatných náležitostí však lze i u dělby moci identifikovat v obecné rovině dvě složky - jedna je představována univerzálně akceptovanými principy (nezávislost a nestrannost soudů), druhá pak prvky, které jsou specifické pro ústavní systém ČR. Zde lze jako př́klad uvést pravidlo, že výkonná moc nemůže vydávat právní předpisy na zákonné úrovni. V jiných státech se s takovým řešením setkat můžeme (typicky např. Francie), nicméně v podmínkách ČR považuji toto pravidlo za součást podstatných náležitostí proto, že pokud by bylo opuštěno, rozpadlo by se aktuálně platné řešení horizontální dělby moci, resp. mnoho jeho složek by přestalo dávat smysl. Jedinou možností by bylo přistoupit ke komplexnímu přepracování celého ústavního systému, čímž by však již došlo k přeměně současného ústavního režimu - bylo by nutné přijmout novou ústavu a změnit tak českou ústavní identitu. V každém př́padě prolomení principu výlučné zákonodárné pravomoci Parlamentu bez dalších souvisejících změn považuji za rozporné s podstatnými náležitostmi demokratického právního státu v podmínkách ČR, nebot’ to narušuje princip dělby moci v souvislosti s principem suverenity lidu.

Trochu problematičtějš́ jsou systémové zásahy do principu dělby moci. Jako příklad lze uvést změnu rozsahu kontrasignovaných pravomocí, změnu formy vlády směrem k poloprezidentské či dokonce změnu Parlamentu na jednokomorový. Podle zkušeností řady jiných ústavních systémů takováto organizace systému dělby nevede k odstranění demokracie nebo právního státu. Na druhou stranu Ústava USA vylučuje změnu Ústavy USA, která by měnila poměr zastoupení států v Senátu, bez souhlasu státu, kterého se to týká, a podobné ustanovení obsahuje také australská Ústava (Murphy 2007, 504).

U změny formy vlády nebo existence druhé komory je opět možné argumentovat tím, že v podmínkách ČR by představovaly natolik zásadní změnu ústavního systému, že by si to vyžádalo přijetí nové ústavy. Je otázkou, zda by to již bylo zásahem do podstatných náležitostí demokratického právního státu, nebot' Ústava ČR sice tento postup z pochopitelných důvodů nepředvídá, ale také jej nevylučuje. Na druhou stranu by však takovýto zásah znamenal změnu ústavní identity, nebot' forma vlády i bikameralismus představují podstatné složky vymezení ústavního systému Č́R. Z pohledu univerzální složky demokratického právního státu by změna formy vlády nebo zrušení Senátu nepředstavovaly nepř́ípustný zásah do podstatných náležitostí demokratického právního státu, byly by však změnou principů specifických pro demokratický právní stát v ČR. Bylo by tak možné je změnit jedině přijetím nové ústavy (Murphy 2007, 506). 
Nyní se ještě pokusím identifikovat ty prvky principu dělby moci v univerzálním pojetí, jejichž změna by již byla nepřípustná. Jako určité obecné východisko lze konstatovat, že ústavodárce má daleko širší diskreci v oblasti organizačních složek principu dělby moci, nebot' konkrétní realizace dělby moci včetně systému brzd a rovnovah je v každém ústavním systému jiná a dosti zásadně se mezi různými státy liší. Toto platí zejména o vztazích mezi mocí zákonodárnou a výkonnou. Postavení moci soudní je již daleko více spjato s formální a materiální složkou demokratického právního státu, což se ostatně odráží i ve výčtu principů demokratického právního státu např. v principu soudní ochrany či nezávislosti soudů a soudců.

Za esenciální pro existenci demokratického právního státu je nutno považovat pravidlo, aby soudy rozhodovaly o otázkách právních, nikoliv politických, aby rozhodovaly jen na návrh ${ }^{47} \mathrm{a}$ aby soudy právní otázky rozhodovaly skutečně nezávisle, bez ohledu na politické zájmy reprezentované př́slušníky moci zákonodárné a výkonné. Ústavní soud musí striktně zůstávat v rovině negativního zákonodárce, $\mathrm{s}$ čímž je částečně $\mathrm{v}$ rozporu jeho př́stup $\mathrm{v}$ rámci kontroly ústavnosti právních předpisů, kdy ruší nejen celá ustanovení, ale dokonce i jednotlivá slova nebo části slov, čímž vlastně obsahově mění význam zákonem stanoveného pravidla a přechází tak do pozice pozitivního zákonodárce. Přijatelné je podle všeho oprávnění ÚS vyzvat zákonodárce ke změně nevyhovující právní úpravy. Musí být tedy zachováno přesné a úzké vymezení soudních kompetencí a př́sná oddělenost moci soudní od moci zákonodárné a výkonné směřující $\mathrm{k}$ zajištění nezávislosti a nestrannosti soudi̊ a soudců.

Ve vztazích mezi mocí zákonodárnou a výkonnou je nejpodstatnější zachování zásady suverenity lidu, která je zajištěna odpovědností veřejných funkcionářŭ, at' již ve formě politické, civilní, trestní či ústavní odpovědnosti. Porušením principu dělby moci by však byla existence neodpovědné moci, nebot' ta by se mohla v důsledku chovat zcela arbitrárně a bez možnosti kontroly ze strany suveréna, tedy lidu. Koncept neodpovědného prezidenta (čl. 54 odst. 3 Ústavy ČR) dodnes značně komplikuje úvahy o postavení hlavy státu, byt' po zavedení př́mé volby a rozšíření pojetí ústavního deliktu již o neodpovědnosti patrně nelze hovořit. Citované ustanovení tak lze vykládat nejspíše v tom smyslu, že prezident nenese politickou odpovědnost před jiným ústavním orgánem.

Zcela evidentním zásahem podstatných náležitostí demokratického právního státu by byla situace, kdy by se $\mathrm{v}$ rukách jednoho orgánu začalo koncentrovat velké množství kompetencí takovým způsobem, že by mohl vládnout sám, bez možnosti ostatních orgánů do toho jakkoliv zasahovat. K tomu by došlo třeba v situaci, kdy by vláda mohla přijímat zákony (a pak je hned provádět), nebo kdyby byla zrušena soudní kontrola ústavnosti (Parlament by byl nekontrolovatelný v oblasti zákonodárství). Podstatné je, aby existovala soudní kontrola ústavnosti

${ }^{47}$ U této zásady lze připustit odůvodněné výjimky např. u nesporných řízení v civilních věcech. 
právních předpisů iniciovaná parlamentní menšinou nebo jednotlivcem. Přestože by bylo možné tyto požadavky zajistit i bez existence Ústavního soudu, domnívám se, že jeho zrušení by v českých podmínkách již představovalo zásah do podstatných náležitostí demokratického právního státu, protože existence Ústavního soudu zajišstuje také vnitřní rovnováhu v rámci moci soudní, a např̀. v difúzním modelu kontroly ústavnosti obecnými soudy je těžko proveditelná abstraktní kontrola ústavnosti.

Domnívám se, že daleko př́ísněji musí být chráněny principy, jež zajištují formální složku demokratického právního státu. Na rozdíl od demokracie, která může být zajištěna velmi odlišnými cestami, právní stát je naopak velmi unifikovaný koncept, jehož základní principy jsou všude stejné. Je to dáno skutečností, že i jen velmi malý zásah do těchto základních principů již znamená zásah do podstaty právního státu. Tomu odpovídá i jejich povaha, která je daleko bližší pravidlům než principům, proto u nich v zásadě nelze provádět vyvažování. To ve výsledku znamená, že i relativně malý zásah do těchto principů již představuje porušení čl. 9 odst. 2 Ústavy ČR. Nelze tak zásadně připustit, aby některé otázky mohly být regulovány v podzákonných předpisech (výhrada zákona), nebo aby právní předpis nebyl obecný, resp. aby měl obsahově povahu rozhodnutí v konkrétní jednotlivé věci. Stejné tak není možné omezit soudní ochranu ${ }^{48}$, nelze tolerovat denegatio iustitiae, a není ani možné zrušit bez náhrady soudní kontrolu ústavnosti právních předpisů.

V oblasti právní jistoty je nutno za podstatnou náležitost demokratického právního státu z pohledu čl. 9 odst. 2 Ústavy ČR považovat princip výhrady zákona, tedy princip, podle nějž určité otázky lze upravit výhradně zákonem, tedy právním předpisem schváleným Parlamentem ČR. U tohoto principu je zajímavé, že není univerzálně sdílen všemi demokratickými právními státy - jako př́klad lze uvést např. Francii, kde vláda může vydávat nařízení se silou zákona a Parlament může zákonem upravovat pouze otázky, které mu ústava výslovně svěřuje. Jedná se tedy o princip sdílený pouze určitou podskupinou demokratických právních států (typicky např. Německo nebo Rakousko).

Z pohledu ústavního systému ČR se však jedná o jeden z ústř̌edních principů, který se dále projevuje $\mathrm{v}$ ústavních řešeních jiných otázek, jako např. ratifikace mezinárodních smluv, soudní kontrola ústavnosti, vztah Poslanecké sněmovny a vlády, nebo zmocnění k vydávání předpisů územními samosprávnými celky. Domnívám se, že nabourání nebo opuštění principu výhrady zákona by vedlo k zásadnímu narušení současné struktury českého ústavního systému a v konečném důsledku ke změně ústavní identity.

${ }^{48}$ Srov. Nález Ústavního soudu ze dne 25. června 2002, sp. zn. Pl. ÚS 36/01, část VII. (publikován pod č. 403/2002 Sb.), kde ÚS konstatoval, že snížení dřive dosažené úrovně procedurální ochrany základních práv by bylo porušením čl. 9 odst. 2 Ústavy ČR. 
Jediný způsob, jak by bylo možné tuto změnu provést korektně tak, aby nedošlo k porušení čl. 9 odst. 2 Ústavy, tedy aby ČR nepřestala být demokratickým právním státem, by byla komplexní změna mnoha prvků ústavního pořádku, a tím by došlo ke změně ústavní identity ČR, nebot' by se již jednalo o jiný ústavní režim, než současný. Bylo by patrně možné, aby i tento nový režim byl demokratickým právním státem, ale postaveným na odlišných zásadách, než současný režim. Patrně by se tím změnila forma vlády, vztahy mezi ústředními orgány, procedurální zásady ochrany základních práv a svobod a další.

Dále lze v oblasti právní jistoty považovat (kromě již výše zmíněných principů) za podstatné náležitosti demokratického právního státu:

a. povinnost státu publikovat všechny obecně závazné právní předpisy před tím, než nabydou účinnosti,

b. princip enumerace veřejnoprávních pretenzí,

c. výhradu zákona, včetně zásad nullum crimen sine lege a nulla poena sine lege,

d. princip ústavně konformní interpretace právních předpisů.

V oblasti procedurálních záruk pak za součásti podstatných náležitostí demokratického právního státu považuji:

a. princip presumpce neviny,

b. právo na soudní přezkum každého rozhodnutí veřejné moci, jímž se zasahuje do ústavně zaručených základních práv jednotlivce,

c. právo na zákonného soudce, tedy soudce určeného nikoli arbitrárně, nýbrž na základě předem stanovených pravidel.

\section{ZÁVĚR}

Při vymezení obsahu pojmu podstatné náležitosti demokratického právního státu je nutné zohlednit jako východisko zejména skutečnost, že tento pojem hraje v ústavním systému ČR pět možných rolí:

a. klauzule věčnosti,

b. referenční hledisko přezkumu,

c. materiální jádro ústavy,

d. zachycení ústavní identity ČR,

e. hodnotové ukotvení Ústavy ČR.

Po rozboru všech pěti uvedených rolí, které může pojem podstatných náležitostí demokratického právního státu v ústavním systému ČR plnit, je podle mne nutné odlišit funkci klauzule věčnosti a na to navazující funkci referenčního rámce přezkumu od zbylých tří funkcí, tedy materiálního jádra, hodnotového zakotvení ústavy a ústavní identity. Funkce klauzule věčnosti a referenčního rámce jsou úzce propojeny, jsou hlavním smyslem zakotvení čl. 9 odst. 2 v Ústavě ČR a mají konkrétní právní důsledky. Ostatní tři funkce hrají roli spíše filozoficko-teoretickou, jsou jakýmsi vedlejším efektem existence čl. 9 odst. 2 Ústavy ČR, a nemají 
tudíž konkrétní důsledky pro text Ústavy ČR. Jsou však podstatné pro hodnotové zakotvení systému, pro řešení složitých hodnotových otázek a v tomto smyslu pro rozhodovací činnost Ústavního soudu.

Pro vymezení obsahu pojmu podstatných náležitostí demokratického právního státu z toho podle mne vyplývá, že musí být dostatečně konkrétní, aby bylo možné naplnit roli referenčního hlediska přezkumu. Při vymezení konkrétních obsahových prvků podstatných náležitostí demokratického právního státu však narážíme na několik problémů. Na prvním místě je to neexistence jasné a jednotné definice pojmu demokratický právní stát, což znamená, že i pojem podstatných náležitostí demokratického právního státu se bude postupně v čase vyvíjet, a nelze tedy koncipovat nějakou precizní uzavřenou definici tohoto pojmu.

Při zkoumání, jaké principy považuje za součást podstatných náležitostí demokratického právního státu odborná literatura a Ústavní soud, se nezř́idka ukázalo, že jsou takto identifikovány principy velmi obecné. $Z$ toho lze patrně vyvodit, že se tím rozumí nemožnost tyto principy zcela poprrít nebo odstranit, to by však asi mělo platit pro všechny principy, které pojem demokratický právní stát obsahuje. V rámci principů demokratického právního státu je však nutné najít takové části, které představují jejich esenci, a do nichž nelze zasahovat.

Dalším problémem při vymezení podstatných náležitostí demokratického právního státu je komplexita tohoto pojmu. Lze si dobře představit situaci, kdy dojde k ústavním změnám dotýkajícím se několika různých principů, přičemž každá z nich samostatně by byla akceptovatelná, ovšem ve svém souhrnu by tyto změny znamenaly porušení podstatných náležitostí demokratického právního státu. Stejně tak si lze představit jednotlivou změnu, která se může jevit jako porušení podstatných náležitostí demokratického právního státu, ovšem pokud se provede spolu s jinými opatřeními, může se stát změnou př́ípustnou. Pro aplikaci čl. 9 odst. 2 Ústavy ČR z toho podle mne vyplývá, že je nutné vždy posoudit danou ústavní změnu komplexně a v konkrétním kontextu.

Posledním problémem je otázka, zda mají demokratický právní stát a jeho podstatné náležitosti univerzální charakter nebo zda mají tyto pojmy vymezeny čistě v kontextu ústavního systému ČR. Zastávám názor, že podstatné náležitosti demokratického právního státu, v návaznosti na ideové zdroje Ústavy ČR, obsahují jak univerzální, tak partikulární složku. Jen těžko si lze totiž představit ústavní identitu, která by pouze kopírovala ústavní identity jiných států, na druhou stranu i v české ústavní identitě je jistě prostor pro přihlášení českého ústavodárce $\mathrm{k}$ univerzálním principům uznávaným $\mathrm{v}$ rodině západních demokracií. $Z$ toho vyplývá, že u otázek, kde neexistuje řešení všeobecně považované za jediné možné, musel ústavodárce učinit volbu, která je někdy tak fundamentální a zakotvená v naší ústavní identitě, že není možné toto rozhodnutí zvrátit. Právě zakotvení ochrany podstatných náležitostí demokratického právního státu v čl. 9 odst. 2 Ústavy ČR je projevem absolutní ochrany, které požívají fundamentální hodnoty ústavního systému a základní volby, které ústavodárce při formování ústavního systému ČR učinil. 


\section{BIBLIOGRAFIA}

Alexy, Robert A. 2009a. Pojem a platnost' práva. Bratislava: Kalligram.

Alexy, Robert A. 2009b. Theory of Constitutional Rights. Oxford: Oxford University Press.

Arcioni, Elisa. Australian Constitutional Identity - Complexity and Fluidity. www.jus.uio.no, [cit. 30. června 2015]. Dostupné na <http://www.jus.uio.no/english/research/news-and-events/ events/conferences/2014/wccl-cmdc/wccl/papers/ws9/w9-arcioni.pdf $\$$.

Aulehner, Josef. 2011. Grundrechte und Gesetzgebung. Tübingen: Mohr Siebeck.

Balog, Boris. 2014. Materiálne jadro Ústavy Slovenskej republiky. Žilina: Eurokodex.

Bermeo, Nancy. 2016. „On Democratic Backsliding”. Journal of Democracy 27 (1): 5-19.

Brożek, Bartosz. 2012. Legal Rules and Principles: A Theory Revisited. i-lex 17: 205-226. [online]. www.i-lex.it, [cit. 30. června 2015]. Dostupné na $<$ http://papers.ssrn.com/sol3/papers.cfm?abstract_id $=2378010>$

Cohen, Carl. 1971. Democracy. Athens: University of Georgia Press.

Dahl, Robert A., Ian Shapiro, José A. Cheibub (eds.). 2003. The Democracy Sourcebook. Cambridge: MIT Press.

Dančák, Břetislav, Vojtěch Šimíček (eds.). 1999. Aktuálnost změn Ústavy ČR. Brno: Masarykova univerzita.

Diamond, Larry. 2003. Defining and Developing Democracy. In Robert A. Dahl, Ian Shapiro, José A. Cheibub (eds.), The Democracy Sourcebook. Cambridge: MIT Press.

Dreier, Horst. 1994. „Grenzen demokratischer Freiheit im Verfassungsstaat”. Juristen Zeitung 49 (15/16): 741-752.

Dworkin, Ronald. 1967. „The Model of Rules”. University of Chicago Law Review 35 (1): 14-46.

Dworkin, Ronald. 1977. Taking rights seriously. Cambridge: Harvard University Press.

Dworkin, Ronald. 2013. „The Rule of Law”. Law of Ukraine 4: 7-13.

Fassbender, Bardo. 2003. Sovereignty and Constitutionalism in International Law. In Sovereignty in Transition. Ed. Neil Walker. Oxford: Hart Publishing.

Filip, Jan. 1997. „Zkrácení volebního období”. Parlamentní zpravodaj 12: 132-134.

Filip, Jan. 2003. Ústavní právo České republiky 1. Základní pojmy a instituty. Ústavní základy ČR. Brno: Masarykova univerzita.

Filip, Jan a kol. 2010. Ústava České republiky. Komentářr. Praha: Linde.

Gerloch, Aleš, Jiří Hřebejk, Vladimír Zoubek. 1996. Ústavní systém České republiky. Základy ústavního práva. Praha: Prospektrum.

Gözler, Kemal. 2008. Judicial Review of Constitutional Amendments. A Comparative Study. Bursa: EKIN Press.

Hangartner, Yvo, Stefan Trechsel (Hrsg.). 1986. Völkerrecht im Dienste des Menschen. Festschrift für Hans Haug. Bern: Haupt.

Häberle, Peter. 1986. Verfassungsrechtliche Ewigkeitsklauseln als verfassungsstaatliche Identitätsgarantien. In Völkerrecht im Dienste des Menschen. Festschrift für Hans Haug. Hrsg. Yvo Hangartner, Stefan Trechsel. Bern: Haupt.

Hendrych, Dušan, Cyril Svoboda a kol. 1997. Ústava České republiky. Komentářr. Praha: C.H. Beck. Holländer, Pavel. 2005. „Materiální ohnisko ústavy a diskrece ústavodárce”. Právník 4: 313-336.

Holländer, Pavel. 2012. Základy všeobecné státovědy. Plzeň: Aleš Čeněk.

Isensee, Josef, Paul Kirchhof (Hrsg.). 2004. Handbuch des Staatsrechts der Bundesrepublik Deutschland. Band II: Verfassungsstaat. Heidelberg: C.F. Müller.

Jacobs, Francis G. 2007. The Sovereignty of Law. The European Way. Cambridge: Cambridge University Press.

Jacobsohn, Gary J. 2010. Constitutional Identity. Cambridge, MA: Harvard University Press. 
Jirásková, Věra. 2011. Základní ustanovení předpisů ústavního pořádku. In Václav Pavlíček a kol., Ústavní právo a státovéda. Díl II: Ústavní právo České republiky. Praha: Leges

Kirchhof, Paul. 2004. Die Identität der Verfassung in ihren unabänderlichen Inhalten. In Handbuch des Staatsrechts der Bundesrepublik Deutschland. Hrsg. Josef Isensee, Paul Kirchhof. Band II: Verfassungsstaat. Heidelberg: C.F. Müller.

Kokeš, Marian. 2009. Krátká reflexe současných debat a názorů na nález ÚS ČR Pl. ÚS 27/09 z hlediska jejich obsahu i zpuisobu prezentace. In: Dny práva - 2009 - Days of Law: the Conference Proceedings. Brno: Masarykova univerzita.

Kommers, Donald P., Russel A. Miller. 2012. The Constitutional Jurisprudence of the Federal Republic of Germany. Durham: Duke University Press.

Kudrna, Jan. 2009. „Počátek nového pojetí «ochrany ústavnosti» v České republice”. Acta Iuridica Olomucensia 2: 339-352.

Luhmann, Niklas. 1983. Legitimation durch Verfahren. Frankfurt: Suhrkamp.

Luhmann, Niklas. 1995. Das Recht der Gesellschaft. Frankfurt: Suhrkamp.

Martí, José L. 2013. Two different Ideas of Constitutional Identity: Identity of the Constitution v. Identity of the People. In National Constitutional Identity and European Integration. Eds. Alejandro Saiz Arnaiz, Carina Alcoberro Llivina. Antwerp: Intersentia.

Mikule, Vladimír. 2007. In Vladimír Sládeček, Vladimír Mikule, Jindřiška Syllová. Ústava České republiky. Komentáŕr. Praha: C.H. Beck.

Molek, Pavel. 2014. Materiální ohnisko ústavy: věčný limit evropské integrace? Brno: Masarykova univerzita.

Morawska, Elżbieta. 2003. Klauzula państwa prawnego w Konstytucji RP na tle orzecznictwa Trybunatu Konstytucyjnego. Toruń: TNOiK Dom Organizatora.

Murphy, Walter F. 2007. Constitutional Democracy. Baltimore: John Hopkins University Press.

Pavlíček, Václav. 2011. Kdo je v České republice ústavodárcem a problém suverenity. In $\mathrm{Na}$ křižovatkách práva: Pocta Janu Musilovi k 70. narozeninám. Eds. Marie Vanduchová, Jaromír Hořák. Praha: C.H. Beck.

Pavlíček, Václav a kol. 2011. Ústavni právo a státověda. Díl 2: Ústavní právo České republiky. 1. úplné vydání. Praha: Leges.

Pavlíček, Václav, Hřebejk, Jiří. 1994. Ústava a ústavní řád České republiky. Sv. I. Ústava České republiky. Praha: Linde.

Podhrázský, Michal. 2010. In Jan Filip a kol., Ústava České republiky. Komentářr. Praha: Linde.

Pospíšil, Ivo, Eliška Wagnerová (eds.). 2009. Vladimír Klokočka. Liber Amicorum. In memoriam emeritního soudce Ústavního soudu. Praha: Linde.

Preuss, Ondřej. 2015. Klauzule věčnosti. Je možné odstranit liberálni demokracii? Plzeň: Aleš Čeněk.

Přibáň, Jiř́i. 2007. Právni symbolismus. O právu, času a evropské identitě. Praha: Filosofia.

Radbruch, Gustav. 1946. „Gesetzliches Unrecht und übergesetzliches Recht”. Süddeutsche Juristenzeitung 1: 105-108.

Rosenfeld, Michel. 2012. Constitutional Identity. In The Oxford Handbook of Comparative Constitutional Law. Eds. Michel Rosenfeld, Andras Sajó. Oxford: Oxford University Press.

Rosenfeld, Michel, Andras Sajó (eds.). 2012. The Oxford Handbook of Comparative Constitutional Law. Oxford: Oxford University Press.

Roznai, Yaniv. 2014. Unconstitutional Constitutional Amendments: A Study of the Nature and Limits of Constitutional Amendment Powers. A thesis submitted to the Department of Law of the London School of Economics for the degree of Doctor of Philosophy. London; etheses.lse.ac.uk, [cit. 15. července 2015]. Dostupné na <http://etheses.lse.ac.uk/915/1/Roznai_Unconstitutional-constitutional-amendments.pdf>, s. 204-205. 
Rychetský, Pavel. 2015. In Pavel Rychetský a kol., Ústava České republiky. Zákon o bezpečnosti České republiky. Komentár. Praha: Wolters Kluwer.

Rychetský, Pavel a kol. 2015. Ústava České republiky. Zákon o bezpečnosti České republiky. Komentár. Praha: Wolters Kluwer.

Saiz Arnaiz, Alejandro, Llivina Carina Alcoberro (eds.). 2013. National Constitutional Identity and European Integration. Antwerp: Intersentia.

Sládeček, Vladimír, Mikule, Vladimír, Syllová, Jindřrška. 2007. Ústava České republiky. Komentářr. Praha: C.H. Beck.

Sobek, Tomáš. 2011. Právní myšlení: kritika moralismu. Plzeň: Aleš Čeněk.

Stein, Peter, Shand, John. 1974. Legal Values in Western Society. Edinburgh: Edinburgh University Press.

Syllová, Jindřiška. 2007. In Vladimír Sládeček, Vladimír Mikule, Jindřiška Syllová, Ústava České republiky. Komentářr. Praha: C.H. Beck

Šimíček, Vojtěch. 1999. Komentář k návrhu na vydání ústavního zákona, kterým se měni Ústava $\check{C} R$ - sněmovni tisk č. 359. In Aktuálnost změn Ústavy $\check{C} R$. Eds. Břetislav Dančák, Vojtěch Šimíček. Brno: Masarykova univerzita.

Šimíček, Vojtěch. 2009. Materiálni ohnisko ústavního pořádku, jeho ochrana a nález Ústavního soudu ve věci M. Melčáka. In Vladimír Klokočka. Liber Amicorum. In memoriam emeritního soudce Ústavního soudu. Eds. Ivo Pospíšil, Eliška Wagnerová. Praha: Linde.

Šimíček, Vojtěch. 2010. In Jan Filip a kol., Ústava České republiky. Komentářr. Praha: Linde.

Tomoszek, Maxim. 2010a. „Nezměnitelnost materiálního jádra ústavy jako řešení konfliktu ústavních hodnot". Časopis pro právní vědu a praxi 4: 325-329.

Tomoszek, Maxim. 2010b. Proportionality in Judicial Review of Constitutional Amendments. 8th World Congress of the International Association of Constitutional Law www.juridicas. unam.mx [cit. 15. července 2015]. Dostupné na $<$ http://www.juridicas.unam.mx/wccl/ponencias/9/175.pdf>, s. 6-9.

Tomoszek, Maxim. 2013. „Das Verfassungsrecht Tschechiens und der Slowakei - eine Bilanz 20 Jahre nach dem Zerfall der Tschechoslowakei”. Osteuropa Recht 3: 239-259.

Tomoszek, Maxim. 2015a. „Esenciální obsah základních práv jako součást podstatných náležitostí demokratického právního státu". Jurisprudence 2: 3-15.

Tomoszek, Maxim. 2015b. Podstatné náležitosti demokratického právního státu. Praha: Leges.

Vanduchová, Marie, Jaromír Hořák (eds.). 2011. Na křižovatkách práva. Pocta Janu Musilovi k 70. narozeninám. Praha: C.H. Beck.

Walker, Neil. (ed.). 2003. Sovereignty in Transition. Oxford: Hart Publishing.

Wintr, Jan. 2013. Principy českého ústavního práva. 2. vyd. Plzeň: Aleš Čeněk.

Zbíral, Robert. 2014. „Koncept národní identity jako nový prvek ve vztahu vnitrostátního a unijního práva: Poznatky z teorie a praxe”. Právník 153 (2): 112-133.

\section{Judikatura}

Nález Ústavního soudu ze dne 29. května 1997, sp. zn. III. ÚS 31/97.

Nález Ústavního soudu ze dne 6. února 2001, sp. zn. Pl. ÚS 42/00.

Nález Ústavního soudu ze dne 6. června 2001, sp. zn. Pl. ÚS 46/00.

Nález Ústavního soudu ze dne 25. června 2002, sp. zn. Pl. ÚS 36/01.

Nález Ústavního soudu ze dne 11. června 2003, sp. zn. Pl. ÚS 11/02.

Nález Ústavního soudu ze dne 8. března 2006, sp. zn. Pl. ÚS 50/04.

Nález Ústavního soudu ze dne 16. ledna 2007, sp. zn. Pl. ÚS 36/05.

Nález Ústavního soudu ze dne 24. července 2007, sp. zn. I. ÚS 557/05.

Nález Ústavního soudu ze dne 29. února 2008, sp. zn. II. ÚS 2268/07.

Nález Ústavního soudu ze dne 12. března 2008, sp. zn. Pl. ÚS 83/06. 
Nález Ústavního soudu ze dne 26. listopadu. 2008, sp. zn. Pl. ÚS 19/08.

Nález Ústavního soudu ze dne 10. záŕí 2009, sp. zn. Pl. ÚS 27/09.

Nález Ústavního soudu ze dne 3. listopadu 2009, sp. zn. Pl. ÚS 29/09.

Nález Ústavního soudu ze dne 31. ledna 2012, sp. zn. Pl. ÚS 5/12.

Nález Ústavního soudu ze dne 2. dubna 2013, sp. zn. Pl. ÚS 6/13.

Nález Ústavního soudu ze dne 26. záŕí 2013, sp. zn. III. ÚS 3333/11.

Nález Ústavního soudu ze dne 19. června 2014, sp. zn. III. ÚS 980/13.

Nález Ústavního soudu ze dne 10. července 2014, sp. zn. Pl. ÚS 28/13.

Nález Ústavního soudu ze dne 10. března 2015, sp. zn. II. ÚS 2050/14.

Usnesení Ústavního soudu ze dne 27. února 2007, sp. zn. IV. ÚS 606/06.

\title{
Maxim Tomoszek
}

\section{THE ROLE OF ESSENTIAL REQUIREMENTS OF A DEMOCRATIC LAW-STATE IN THE CONSTITUTIONAL PRACTICE OF THE CZECH REPUBLIC}

\begin{abstract}
When defining the content of essential elements of a democratic Rechtsstaat/ rule of law, it is necessary to take into account in particular the fact that this concept plays five possible roles in the constitutional system of the Czech Republic: the eternity clause, the frame of reference in constitutional review, the material core of the Constitution, the constitutional identity of the Czech Republic, and as a set of core values of the Czech Constitution. Essential elements of a democratic rule of law, in connection with the founding ideas of the Constitution of the Czech Republic, contain both a universal and a specific component. It is hard to imagine a constitutional identity that only duplicates the constitutional identities of other states, on the other hand even in the Czech constitutional identity there is certainly room for the Czech Constitutional Framers to accept the universal principles recognized in the family of Western democracies. This further defines the particular principles understood as essential elements of a democratic rule of law, in the meaning of Art. 9 para. 2 of the Czech Constitution.
\end{abstract}

Keywords: democracy; rule of law; Constitution of the Czech Republic; eternity clause; constitutional principles; constitutional amendments; unamendability of the constitution. 